\title{
Emeğin Etnikleşmesi ve Feminizasyonu: Çay Tarımında Kadın ve Gürcü Emeği*
}

\section{The Ethnicization and Feminization Process of Labor: Women and Georgian Labor in Tea Agriculture}

\author{
Muhammet ÖKSÜZ1 무, Ertuğrul Murat ÖZGÜR² \\ ${ }^{1}$ Araş. Gör., Siirt Üniversitesi, Fen Edebiyat Fakültesi, Coğrafya Bölümü, Siirt, Türkiye \\ ${ }^{2}$ Prof. Dr., Ankara Üniversitesi, Dil ve Tarih Coğrafya Fakültesi, Coğrafya Bölümü, Ankara, Türkiye
}

ORCID: M.Ö. 0000-0002-2255-3111; E.M.Ö. 0000-0002-2146-7721

\section{ÖZ}

Emeğin etnikleşmesi ve feminizasyonu iç içe geçmiş süreçlerdir. Her birinin kendine özgü iç tarihi olmakla birlikte kapitalizm ve neoliberalizmle birlikte yeni bir boyuta taşınmıştır. Bu açıdan cinsiyet ve etnik kimlik emeğin sömürüsü için araçsallaştııılmaktadır. Bu konuda yapılan çalışmalar genel olarak etnisite ve cinsiyetin ücretli emek olarak iş gücü piyasalarında yer alması ile birlikte gündeme gelmiştir. Fakat işgücü piyasalarından önce ulus devlet inşası bağlanımında ırk ve ücretsiz aile emeği olarak kadın konusu daha az araştırıııştır. Bu çalışmada çay tarımında ücretsiz kadın emeği sorunsallaştııımaktadır. Sonrasında Gürcü emeğinin etnikleşme süreçleri tartışılmaktadır. Bu iki süreç çay tarımı merkeze alınarak emek değer teorisi ile açıklanmaktadır. Ayrıca Covid 19 sürecinin de bu olguya nasıl etki ettiği de çalışmanın diğer bağlamını oluşturmaktadır. Etnikleşme ve feminizasyon süreci çok boyutlu ve çok failli bir süreçtir. Bu amaçla farklı yapı ve aktörlerden oluşan 48 kişi ile nitel görüşme yapılmıştır. Görüşmeler kayıt altına alınarak sonrasında çözümlenmiş ve çoklu yapı analizi yapılmıştır. Ayrıca yerel medyada yer alan Gürcü temsil ve algı biçimlerine odaklanılarak bu veriler üzerinden betimsel analiz yapılmıştır. Ortaya çıkmaktadır ki emeğin etnikleşmesi ve feminizasyonu benzer arka plandan beslenmekte ve kriz durumunda birbirinin yerine kullanılmaktadırlar.

Anahtar kelimeler: Emeğin Feminizasyonu, Emeğin Etnikleşmesi, Gürcistan, Türkiye

\section{ABSTRACT}

Ethnicization and feminization of labor are intertwined processes. Although each has its own internal history, they have been taken to new dimensions with capitalism and neoliberalism. In this respect, gender and race are instrumentalized for the exploitation of labor. There have been several studies on the inclusion of race and gender in the labor market in considering wage labor. However, not many studies focus on nation-state building before labor markets, race, and women as unpaid family members. In this study, the issue of unpaid female labor in tea agriculture is examined. It also considers the ethnicization processes of Georgian labor. These two processes are explained by the labor value theory by placing tea agriculture at the center. Moreover, the effect of the Coronavirus disease 2019 (COVID-19) pandemic on the processes will also be discussed. Because the process of ethnicization and feminization are multidimensional and multi-agency processes, qualitative interviews were conducted with 48 people from different structures and actors. The interviews were recorded, resolved, and multiple structure analyses were performed. Survey data applied in a different context in another study for Georgians were also used as data sources in this study as ethnicization and feminization of labor are fed from a similar background and are used interchangeably in case of crisis. Keywords: Feminization of Labor, Ethnizitation of Labor, Georgia, Turkey 


\section{EXTENDED ABSTRACT}

The feminization processes of labor have been studied since 1980. The examination of feminization processes mostly started with the participation of women in the paid workforce. Women's labor is produced as cheap labor in the neoliberal system. In this respect, teaching, care work, health services, and seasonal agricultural work have been feminized both locally and globally. Although the motivation here is explained by the fact that some jobs are seen as women's jobs, it is actually a result of women's labor being flexible and suitable for exploitation. Although feminization processes are primarily discussed within the context of women's participation in the workforce, this phenomenon is actually quite old. Since the establishment of the settled order, women's labor has been seized free of charge. In this respect, jobs such as childcare, cleaning, and cooking are identified with women. According to an Oxfam (2020) report, 75 percent of unpaid care work is covered by women. If a fee were to be paid for this exploitation, it would amount to 10.8 trillion dollars. Different connections emerge when the feminization process, which is built on the inadequacy, emotionality, and suitability of women, is read together with capitalism. Most of the workers who go from Morocco to Spain to pick strawberries are women because, according to employers, women's delicate hands are better suited for picking strawberries. While the woman does the hand picking, the man uses a machine. This is an example of how exploitative relationships have entered the market. These wage and unpaid labor and exploitative relationships are a micro-capital order; they reproduce capitalism. Tea agriculture came to the Black Sea region directly with unpaid female labor. Planting, harvesting, and selling of tea saplings are carried out by women but the money is managed by men. Since men work in tea factories and tea harvesting is primarily associated with women, it creates a free labor area. Neoliberal and demographic transformations in the Black Sea region have caused Georgians to come for the tea harvest. Incoming Georgians constitute wage labor.

Ethnicization of labor goes through a similar process as feminization. To understand the processes of ethnicization, it is necessary to focus on the production of the concept of race and how it is incorporated into labor markets. Although race is assumed to be the production of superstructure, it is actually directly related to the infrastructure. Ethnic distinction is not only something people produce culturally, but also an economic production. There is nothing that the capital system cannot ethnicize in order to exploit labor. Another reason for the ethnicization of tea agriculture through Georgians is the racist approach to Kurds. Unpaid women's labor was reactivated during the COVID-19 pandemic, when Georgians could not come. The most important finding of the study is that women and ethnic labor can easily use interchangeably in case of crisis. Unpaid female labor was used before tea cultivation. With the arrival of the Georgians, the labor in tea farming entered the ethnicization process. The crisis that emerged with COVID-19 has feminized labor.

This study reveals how the feminization and ethnicization processes of labor work, and discusses the common and different aspects of both processes. In addition, when these two processes are approached with Marxism, answers are sought to the questions of how the results change. This study consists of four parts. In the first part, the process of ethnicization and feminization of labor and how it is produced is discussed. The second part deals with the historical and economic dimensions of labor feminization in tea agriculture, and the third part explains the ethnicization of labor through Georgians. While expressing the ethnicization of Georgians, the supply and demand of Georgian labor are evaluated. In the discussion and conclusions part, both results of the research are evaluated and the triad of labor, ethnicization, and feminization is critically discussed. 


\section{GİRIŞ}

Emeğin feminizasyonu 1980'lerden bu yana dünya çapında işgücü piyasalarına daha fazla kadının katılması bağlamında genel olarak var olan artışı tanımlamak için kullanılan bir terimdir. Hem tanımın ortaya çıktı̆̆ 1 yıl hem de kavramın tanımından anlaşılacağı üzere neoliberal dönemde kadının ücretli emeğe katılımına göndermede bulunmaktadır. Emeğin feminizasyonu çok çeşitli bağlamlarda incelenmiş ve inceleme alanı da giderek genişlemektedir. Bir işin feminizasyonunun gerçekleşmesi için kadın emeğinin sosyal olarak kabul ediliyor olması, hedef ülkede kadın emeğine talebin artması, emeğin belgesiz olarak düzenlenebiliyor olması ve aileye karşı sorumluluk olması gibi süreçlerin işlemesi gerekmektedir (Zurabishvili ve Zurabishvili, 2010: 73-74). Emeğin feminizasyonu açıklanırken bazı araştırmacılar ucuz emek arayışının bir sonucu olarak durumu değerlendirirken bazıları ise cinsiyete bağlı çalışma söylemlerinin etkili olduğunu ifade eder (Hossain vd. 2013: 197-198). Bu iki bakış açısının ilki alt yapıya işaret ederken ikincisi üst yapıya işaret etmektedir. Bu iki açılama feminizasyonun farklı anlamlara gelmesine de sebep olmuştur. Feminizasyon özellikle tarımdan sanayi sektörüne geçişte kadınların işgücüne katılımındaki keskin artışı ifade etmek için kullanılmaktadır. Buradaki kullanım doğrudan niceliksel bir artışa işaret etmektedir. Fakat emeğin feminizasyonunun erkeklerde de olmakla birlikte daha çok kadınlarda olan emeğin artan esnekliğini tanımlamak için kullanılmaktadır. Bu ikinci kullanım da politik ekonomi sürecine vurgu yapmaktadır. Bir bakıma iş gücü piyasaları kadınların katılımına uygun hale getirilmiştir. Bir yandan işçi erkeklerin toplu pazarlık güçleri ekonomi politikalarla kısıtlanmış, hane halkında bir kişinin emek sürecine katılması planlanmış ve bu modelin de sürekliliği sağlanmaya çalışılmıştır. Böyle olunca iş güvensizliği artmış ve hane halkında iş gücü piyasalarında olmayan kadın emeği piyasaya katılmak zorunda kalmıştır. Bu zorunluluk ile birlikte emek esnekleşerek sermaye tarafindan kullanışlı hale gelmiştir (Richer, 2012: 1). Bu kullanışlı olma durumu da esnekliği teşvik etmiş ve daha fazla esnekleştirilen kadın emeği de belli iş kollarında feminizasyon süreçlerine dahil olmuştur. 1985-1990 yılları arasında birçok ülkeden veriler toplanarak kadınların işgücü içindeki payı ile uzun vadeli ekonomik kalkınma süreçleri ve yapısal uyumla ilişkili makroekonomik değişiklikler arasındaki ilişkiyi analiz eden çalışmalar (Çağatay ve Özler, 1995: 1883) da benzer sonuçlar elde etmişlerdir. Hatta bu ekonomik gelişmeler ile U profil arasında yapısal bir uyum tespit etmişlerdir (Gaddis ve Klasen, 2011; Lechman ve Kaur, 2015). Bu feminizasyon süreci ile birlikte birçok bağlamda bu sürecin uğrağı olmuştur. Bu esneklik göçün (Yoshimura, 2007), ev içi duygusal emek ile ücretli emeğin (Gutierrez-Rodriguez, 2014), eğitim sektörünün (Filali Adi vd. 2013), tarımın (Reigada-Olaizola, 2011), emek piyasasındaki serbestleşme dinamiklerinin (Assaad, 2004), işgücü maliyetlerinin düşürülmesinin (Caraway, 2005) de feminizasyona uğramasına sebep olmuştur. Bu durum sadece emeğin piyasa tarafından bu şekilde örgütlenmesi ile ilgili değildir aynı zamanda ev içi ücretsiz emeğin inşa edilmesi ile piyasadaki kadın emeğinin inşa edilmesinin birbirine paralel olması (Mahmud, 2003: 2-3) ile de ilgilidir.

Türkiye'de yapılan çalışmalar da feminizasyon süreçleri incelenirken sıklıkla ücretli emek üzerinden değerlendirilmiştir. Küreselleşme kapsamında Trabzon'daki feminizasyon sürecinin hizmet sektörü bağlamında (Kurt, 2014), sağlık sektörünün feminizasyonu piyasa ve yapı bağlamında inceleyen çalışmalar da vardır (Urhan ve Etiler, 2011). Yayıncılığın (Yücel ve Orhan, 2018), enformel sektörün (Ergüder, 2006), tekstil sektörünün (Çakmak ve Yaman, 2018) feminizasyon süreçleri incelenmiştir. Fakat bu konuda ön plana çıkan nitelikli çalışmalarda göç teorilerinde kadının yeri (Dedeoğlu ve Gökmen, 2020), yoksulluğun feminizasyonu (Yıldırımalp ve Özdemir, 2013), Türkiye'deki aile ve kadın emeğinin toplumsal cinsiyet boyutu (Dedeoğlu, 2000), sosyal devlet politikalarının feminizasyon sürecini üretmedeki rolü (Dedeoğlu, 2009), küresel endüstri üretiminde emekçi kadınlar (Dedeoğlu, 2007), sosyal entegrasyonda Türkiye'deki kadın işçiler (Dedeoğlu, 2014), neoliberal piyasanın patriarkal çıkmazında kadın emeği (Dedeoğlu ve Öztürk, 2010; Dedeoğlu, 2010; Toksöz vd. 2012; İlkkaracan, 2013) ayrıntılı bir şekilde incelenmiştir. Bu literatür zaman zaman ücretsiz emeğin üretilmesinde feminist bir perspektifle baksa da genel olarak emeğin feminizasyonunun ücretli emeğe dönüştüğü alana odaklanmaktadır.

Emeğin etnikleşmesi bağlamı feminizasyonda olduğu gibi işgücü piyasaları bağlamında değerlendirilmektedir. Bu yapılırken de sıklıkla etnisite kavramının üretimi ve bunun piyasalara dahil edilerek nasıl sömürüldüğü ilişkisi ön planda tutulmaktadır. $\mathrm{Bu}$ açıdan da emek teorisi ile birleştirilmektedir. Her ne kadar etnisitenin üst yapı üretimi olduğu varsayılsa da aslında alt yapı ile doğrudan ilişkili olmaktadır. Etnik ayrım sadece insanların kültürel olarak ürettiği bir şey değil aynı zamanda ekonomik bir üretimdir. Bu açıdan İngiltere'deki tekstil sektörünün (Jackson, 1992), Kolombiya çiçek endüstrisinin (Sanmiguel-Valderrama, 2007), Afrika'daki Çinli işverenlerin siyahlığı (Sautman ve Hairong, 2016) etnikleştirdiği ön plana çıkmaktadır. Kuzey-Güney arasındaki etnikleştirme pratiği hakim unsur tarafindan sonradan gelenlere yönelik olurken, Güney-Güney arasında ise sermayenin 
hangi grubun elinde olduğuna bağlı olarak etnikleşme süreci değişebilmektedir. Çünkü Afrika'da bulunan Çinlileri, Afrikalılar değil aksine Çinliler Afrikalıları etnikleştirme sürecine itmektedir. Ayrıca bizim konumuz açısından önemli olan ücretli tarım işçiliğinin küresel ölçekte etnikleştĭgine ilişkin birçok çalışma vardır. Kanada'da Karayipliler, Meksikalılar tarım işçiliği bağlamında etnikleşmiştir (Satzewich, 2000; Preibisch ve Binford, 2007; Block vd. 2014). Amerika'da ise neredeyse Latin Amerika'dan gelen tüm emekçiler belli iş kollarında etnikleşme sürecine dahil edilmişlerdir (Maldonado, 2009). Bu sadece Güney Amerika'dan kuzeye olan hareketlerde değil aynı zamanda Güneydoğu Asya'dan Amerika'ya gelen nüfus hareketlerinde de etnikleşme gözlemlenmektedir (Baldoz, 2004: 970). Bu hareketlilik göçün de belli iş kollarına yaptığı hareketler bakımından da etnikleştiğinin işareti olmaktadır (Carter vd. 1996). Etnikleşme sürecinin analiz eden çalışmalar sıklıkla bunu neoliberal politikalar çerçevesinde ele almıştır (Lunn, 2000; Thomas, 2010; Block vd. 2014; Ferrer vd. 2017; Vincze, 2019; Petrovici vd. 2019).

Bazı çalışmalar etnikleşme süreci ile feminizasyon sürecini beraber ele almaktadır. Bu durum emek değer teorisi ile her iki sürecin birlikte değerlendirildiği keşisimsellik teorisine denk gelmektedir (Knight, 2016: 310-311). Bu da emeğin etnikleşme süreçleri ile feminizasyon süreçlerinin arka planında nasıl üretildiğini kısımlarında bir ortaklık oluşturup emek süreci ile birleştirilerek yapılmaktadır. Burada da işgücü etnikleşme süreci ile üretilirken feminizasyon ona yardımcı görevi görmekte ve tek bir işin yapılma biçimleri kategorilere ayrılarak cinsiyetlendirilmektedir (Sanmiguel-Valderrama, 2007: 71-72). Örneğin bir tarımsal emek bir etnik unsur üzerinden etnikleştiyse aynı zamanda tarım içerisinde yer alan toplama, taşıma, paketleme süreçleri de cinsiyetlendirilmektedir. Başka bir örnekte ise yoksulluk bir etnik grup üzerinden inşa edildiyse aynı zamanda etnik grup içerisinde de yoksulluk feminizasyona uğramaktadır (Szelenyi, 2001; Kwok ve Wallis, 2008). Bu durum etnofeminizasyon olarak kavramsallaştırılabilir.

Türkiye'de etnikleşmeye ilişkin yapılan çalışmaların çoğu mevsimlik tarım işçilerinin (Karaman ve Yılmaz, 2011; Çınar ve Lordoğlu, 2015; Geçgin, 2017) ve inşaat sektörünün çoğunluğunun Kürtlerden oluşması üzerinden yapılmaktadır. Rusya'dan Türkiye'ye ulusaşırı göçün (Deniz ve Özgür, 2010), Rus gelinlerin Türkiye'ye göç etmesi (Deniz ve Özgür, 2013); Rus kadınların emek göçü (Deniz ve Özgür, 2015), Filipinli dadı göçü (Deniz, 2018), politik ekonomi olarak karma evlilikler (Deniz ve Özgür, 2020) gibi çalışmalar her ne kadar kendi bağlamlarında konuları ele alsalar da aslında emeğin feminizasyon ve etnikleşme süreçlerini de ortaya koymaktadırlar. Hemşehri dernekleri ile ilgili yapılan çalışmalara (Kurtoğlu, 2005; Köse, 2008; Özkiraz, 2012; Akgiş ve Karakaş, 2018; Öksüz, 2018) bu açıdan yaklaşıldığında emeğin hemşerileştiği sonucu ortaya çıkmaktadır. Çünkü hemşehrileşme belli ölçüde kent mekânında emeğin ağlar yoluyla dağıtılmasını içermektedir. $\mathrm{Bu}$ açıdan bu çalışma çay hasadının Gürcü emeği üzerinden etnikleşmesini içermektedir. Bunu yaparken de emeğin etnikleşme sürecinin nasıl inşa edildiği incelendikten sonra emek teorisi bağlamında değerlendirilmektedir. Bu çalışmayı diğer çalışmalardan farklı kılan şey çay tarımını merkeze alarak etnikleşme süreçlerini Gürcüler üzerinden, ücretsiz feminizasyon süreçlerini çay bölgesindeki kadınlar üzerinden okumaktadır. Ayrı ayrı bu iki sürecin ortaklıkları ve birbirinin yerine kriz durumlarında nasıl kullanıldıklarını tartışmaktadır. Bu çalışma dört bölümden oluşmaktadır. İlk bölümde emeğin etnikleşme ve feminizasyon süreci ve nasıl üretildiği ele alınmaktadır. İkinci bölümde çay tarımında emeğin feminizasyonunun tarihsel ve ekonomik boyutları ele alınırken üçüncü bölümde Gürcüler üzerinden emeğin etnikleşmesi açıklanmaktadır. Gürcülerin etnikleşmesi ifade edilirken de tarihsel arka planı Gürcü emeğinin arz ve talebi değerlendirilmektedir. Tartışma ve sonuç bölümünde ise hem araştırmanın sonuçları değerlendirilmekte hem de emek, etnikleşme ve feminizasyon üçlüsü eleştirel bir boyutta ele alınmaktadır.

\section{YÖNTEM}

Yorumlayıcı ve eleştirel bir sosyal bilim anlayışı ile tasarlanan bu çalışmada konu bağlamında olay ve olgular ayrıntılı bir şekilde okunmuş ve incelenmiştir. Yorumlayıcı ve eleştirel sosyal bilim yaklaşımının veri toplamaya yönelik temel araçları gözlem ve saha araştırmasıdır. Bu tekniklerin kullanımı için araştırmacıların ilgili grupla etkileşim haline olması gerekir. Araştırmacılardan biri Rize'de doğmuş ve uzun süre çay tarımı ile ilgilenmiş̧ir. Bu açıdan araştırmada ifade edilene etnikleşme ve feminizasyon süreçlerini yakından deneyimlemiştir. Diğer araştırmacının bu deneyimden uzak olmasının da araştırma sürecinin içerden (insideness) ve dişardan (outsideness) bir bakışla inşa edilmesine yardımcı olmuştur. Araştırma konusu birçok aktör ve yapı ile ilişkili olduğundan olguları anlamak amacıyla veri çeşitlemesi (triangulation) yapılmıştır. Buna göre etnikleşme ve feminizasyon merkeze alınarak bu olguları açıklamak ve anlamak için gerekli olan yapı ve aktörler tespit edilmiştir. Bu olguları açılamak için olgunun literatürdeki yeri tespit edilmiş, medya temsillerine bakılmış, tarihsel bilgilerden yararlanılmış ve ilişkili aktörlerle görüşmeler yapılmıştır. Saha araştırma sürecinde (Mayıs-Ağustos: 2019) bir veri toplama 
aracı olarak gözlemden de yararlanılmıştır. Gözlemle elde edilen veriler diğer verilerle birleştirilerek doğrulanmıştır. Görüşme tekniğinde görüşülen kişilerin kim olduğu önemlidir; bu açıdan kiminle ne için görüşüleceğini tespit edebilmeyi belirleyen şey araştırma problemidir. Çay tarımına yönelik feminizasyon süreçlerini anlama adına özellikle çay bitkisinin bölgeye gelmeden önceki süreci ve Gürcü tarım işçilerinin henüz bölgeye çalışmaya gelmediği dönemi bilen toplumun kolektif hafıza taşıyıcısı olan kişilerle görüşme yapılmıştır. Bu kişiler seçilirken amaçlı örneklem kullanılmıştır. Bu kişilerin özellikleri yaşlarının 70-80 arasında olmasıdır. Bu örneklem içinde yer alan özellikle kadınlar bir başka köyden bir başka köye evlilik yolu ile göç ettiği için her iki köyün deneyimini aktarmış olması açısından önemlidir. Gürcüler üzerinden emeğin etnikleşmesini anlama adına Gürcülere yönelik olumsuz ifadeler ve mitlere bakmak gerekir. Çünkü ötekileştirme mekanizmaları emeğin neoliberal sistemde etnikleşmesini kolaylaştıran bir mekanizmadır. $\mathrm{Bu}$ amaçla hem medyada yer alan olumsuz ifadeler hem de işveren ve aracılar ile görüşmeler yapılmıştır. Bu görüşmeler yapılırken de amaçlı örneklem kullanılmıştır. Bazı durumlarda Gürcülere ve aracilara ulaşmak için kartopu örneklem tercih edilmiştir. Çünkü grupla ilişkilenmek için kişilerin tanıdık ilişkisini ortaya koyan sosyal sermayelere ihtiyaç vardır. Kartopu örneklem tek bir noktadan başladığında birbirine benzer sonuçlar üretebileceği riski taşıdığından bu riski ortadan kaldırma adına farklı başlangıç noktaları tercih edilmiştir. Yapılan görüşmelerin bir kısmı işveren ve esnaf üzerinden gerçekleştĭgi için görüşme planlanmamış bir şekilde odak grup görüşmesine dönüştüğü durumlar ortaya çıkmıştır. $\mathrm{Bu}$ da farklı görüşlerin temsilini sağlamıştır. Nitel araştırma tasarımı içerisinde kaç kişi ile görüşülmesi gerektiği konusunda herhangi bir sayı ifade edilmez. Katılımeı sayısını belirleyen şey problem ve olgunun kendisidir. Fakat görüşülen kişilerde belli bir çeşitliliğe ulaştıktan sonra elde edilen veriler kendini tekrar etmeye başladığında nitel araştırmada doygunluğa erişildiği söylenebilir. $\mathrm{Bu}$ sebeple çay bölgesi toplumunun olguyla ilişkili olabilecek 48 kişi ile nitel görüşme yapılmıştır. $\mathrm{Bu}$ kişiler arasında aracı, kolektif bellek taşıyıcıları, emniyet mensupları, Gürcü işçiler, öğrenciler ve esnaf gibi kişiler bulunmaktadır. Araştırma sürecinde görüşmelerden elde edilen ses kayıtları çözümlenmiş ve belli kategorilere ayrılmıştır. Bu kategoriler çay tarımı öncesi, sonrası, etnikleşme, feminizasyon, ötekileştirme gibi kategorilerdir. Veri seti içindeki ifadeler bu kategorilerden hangisi ile ilgiliyse onun altına dâhil edilmiştir. $\mathrm{Bu}$ çalışma yapıyı ortaya koymaya yönelik bir çalışma olduğu için yoğun alıntıların yapıldığ 1 betimsel analizden farklılaşmaktadır. Bunun için bu çalışmada kişilerin ifadelerini doğrudan alıntılayarak ifade etmek yerine verilerden ortaya çıkan bağlamlar etnikleşme ve feminizasyonla ilişkisi ekseninde yorumlanmıştır. Başka bir deyişle farklı aktörlerin bir konudaki benzer söylemlerinden tek bir bulgu inşa edilerek araştırmaya dahil edilmiştir. Görüşmelerin yapıldığı mekânsal birimler; Rize Merkez, Kendirli Beldesi, Rize'ye bağlı İyidere, Derepazarı, Pazar, Güneysu ilçeleri ve köyleri ve Trabzon'a bağlı Of ilçesi ve köyleridir.

Nitel bir araştırmada güvenilirliği/geçerliliği sağlamak için belli taktikler gereklidir. Bunu sağlamak için araştırmacılar olarak sahada esnek davranılmış ve karşılaşılan yeni durumlara ayak uydurmak için stratejilere başvurarak yeni sorular üretilmiştir. Bulguların anlamlı ve tutarlı oluşu geçerliliği artırmaktadır. Araştırmada farklı aktörlerin birbirinden bağımsız ifadeleri arasında çelişki olmaması geçerliliği arttıran bir unsurdur. Araştırma sırasında elde edilen ön bulgular sosyal ve kültürel çevre ile paylaşılarak tartışmaya açılmış olması da bir diğer geçerliliği sağlayan stratejidir. Araştırma sonuçlarının genellenebilir oluşu; literatürde özellikle sınırlar arası emek hareketliliği çalışmaları ile benzer oluşu ile mümkün olmaktadır. Zaten örneklemin çeşitli oluşu da buna imkân sağlamaktadır.

\section{EMEĞİN FEMİNIZASYONU VE ETNIKKLEȘMESİ}

Feminizasyon süreçlerine ilişkin literatür yoğunlukla ücretli ve güvencesiz işlerde kadınların oransal olarak artması fakat nitelik yönünden değişmemesine işaret etmektedir. Bu yönüyle feminizasyon süreçlerinin araştırmalara konu olması kapitalist ilişkiler bağlamında liberalleşme ile birlikte yaygınlık kazanmıştır. Burada önemli olan husus henüz yeterli derecede ücretsiz tarım emeğinin feminizasyon süreci ile değerlendirmemiş olunmasıdır. $\mathrm{Bu}$ yeterli olmama durumu feminizasyon kavramının yukarda söz konusu ekonomik yapının gelişmesi ile birlikte ortaya atılması ile ilişkilidir. Giderek artan oranda feminist ekonomi politik çalışmaları feminizasyon bağlamında canlanmaktadır. Bu konuda öne çıkan ilk olarak tanıma politikasıdır. Bu politika kültürel ve sembolik değişim içerisinde grupların (kadınların) tanınması için mücadelelere odaklanmaktadır. Yeniden dağıtım politikası ise büyük ölçüde sosyo ekonomik adaletsizliklere odaklanır. Bu açıdan Vasko (2002: 55-56) farklı teorileri birleştirerek kavşak teorileştirme ile olguya yaklaşır. $\mathrm{Bu}$ açıdan da feminizasyon ve etnikleşme süreçlerini birleştirerek politik ekonomi yapar. Bunun için de işgücünün etnikleşmesi ve feminizasyonu süreçlerini keşisimsellik üzerinden geniş bir yelpazede değerlendirmek gerekmektedir (Vosko, 2002: 76-78). Bu bağlamda iş gücünün etnikleşme ve feminizasyon süreçlerini ele almada Marxist feministler önemli bakışlar sunarlar. Marxist feministler antikapitalist siyasete sunduğu en büyük katkılarında biri de bu 
anlamda cinsiyet ve etnisiteyi bütünleştiren ve toplumsal yeniden üretime odaklanan bir sinıf analizidir (Luxton, 2014: 153). Bu açıdan da aslında Marx'ın emek teorisi giderek feminizasyona da uğramaktadır (Sanmiguel-Valderrama, 2007: 71). Fakat feminizasyon ifadesi ancak belli çelişkileri ifade ettiği kabul edilerek kullanılmalıdır; çünkü bu süreç ne toplumsal cinsiyet eşitliğine yol açmış ne de toplumsal cinsiyetli iş bölümünü ortadan kaldırmıştır. Emek sürecindeki bu eğilimler (feminizasyon ve etnikleşme) emek gücünün kapitalist kontrol stratejilerine işaret eder (Hardt ve Negri, 2011: 143-153). Feminizasyon ve diğer süreçler ile emeğin tüm biçimleri piyasa esnekliğine denk düşen sayısız modele göre örgütleyerek bir müphemlik dayatılır. Müphemlik çalışma zamanı ile çalışılmayan zaman arasındaki ayrımı yok ederek işçilerin her zaman çalışmasını değil ama daima işe uygun olmasını gerektiren, işçilerin zamanla bağını belirleyen bir kontrol mekanizmasıdır. Müphemlikle birlikte işçilerin zamanları üzerindeki kontrollerini yitirdikleri özel bir yoksulluk türü yaratır; zamansal yoksulluk (Hardt ve Negri, 2011: 154-155).

Bazı araştırmacılar işgücünün feminizasyonu kavramı içerisinde bir alt alan olarak işgücü piyasasında kadınlar arasında etnik ilişkilerin nasıl olduğuna odaklanarak bu şekilde incelemeyi de önermişlerdir (Cranford vd. 2003: 476). Buna rağmen etnikleşme süreçlerini incelenirken feminizasyon süreçlerinden bağımsız olarak incelenme eğilimi vardır. Aslında etnikleşme ve feminizasyon süreçleri benzer arka plandan beslenmekte hem de kimi zaman birbirinin yerini almaktadır. Ücretli piyasada işverenler geleneksel olmayan ve yüksek değerli tarımsal ihracat üretimi ile ilgili emek yoğun görevler için kadın işçileri tercih etmektedir. Kadınlar itaatkâr, uysal olarak kabul edilir. Kadınların bakım ve sabır gerektiren görevler için daha fazla beceri ve çalışma koşulları konusunda esnekliğe sahiptirler ya da öyle olduğu bu şekilde üretilir. Tarım işletmelerinde eşitsiz cinsiyet ilişkileri geleneksel formda olduğu haliyle yeniden üretilir. Kadınlar tarlalarda ayıklama ve budama, seçme, kesme, ambalajlama, sıralama ve sarma gibi emek yoğun görevleri yerine getirir. Erkekler, kasalar kaldırma ve sera inşaatı gibi güç gerektiren veya traktör ve kamyon sürme ve ekipman bakımı gibi makineleri içeren görevleri yaparlar. Kadınların çalışmalarının vasıfsız olarak görülme olasılığı daha yüksektir ve kadınların daha yüksek ücretli işler için uygun olmalarını sağlayacak eğitim ve beceri kazanma olasılıkları daha düşüktür (Lastarria-Cornhiel, 2006: 5-6). Burada üzerinde durulmas1 gereken kadınlar emeklerini ister ücretli ister ücretsiz kullansın maruz kaldıkları şeyler benzerdir. Yani bu eşitsiz ilişkiler salt ücretli işgücüne katılımı ile görünürlük kazandığına ilişkin alg1 bizi yanıltmamalıdır. $\mathrm{Bu}$ alg1 emeğin feminizasyonunun kapitalist üretim ilişkilerine ve neoliberalizm üzerinden incelendiği için mümkün olmaktadır. Bu açıdan da toplumsal cinsiyet eşitsizliğini ücretli emeğe katılım öncesi ilişkilerde aramak gerekmektedir. Çünkü geleneksel olarak kırsal emek, çay tarımı da söz konusu olduğunda sürekli olarak ücretsiz kadın emeği tarafından yapılmaktaydı.

Erkeklerin ülke içi veya uluslararası göçe katılmaları ile birlikte erkeğin tarıma ilişkin sorumlulukları da kadınlara yüklenebilmektedir. Bazı durumlarda toplumsal cinsiyet eşitsizliği o derece kuvvetlidir ki kadının kamusal alana çıkmasına şiddetle karşı çıkıldığı için erkeğin göçü ile birlikte tarımsal üretim düşebilmektedir. Erkeklerin göçü ve buna eklenen arazi mülkiyetinin yoğunlaşması ile birlikte giderek daha fazla kadın bağımsız çiftçiye de dönüşebilmektedir. Mülkiyet küçüldükçe kadın daha fazla söz hakkına sahip olabilmektedir (LastarriaCornhiel, 2006: 8-9). Bu durum da hanelerin kadın reisli olması sonucunu doğurmuştur. Bazı durumlarda çocukların eğitim almasını isteyen kadınlar bu durumda çocukların yaptığı diğer işleri de kadınlar yapmak durumunda kalmaktadır. Liberalizm ile tarımda yaşanan dönüşüm sebebiyle küçük ölçekli geleneksel tarım ortadan kalmış, şirketler ölçeğinde tarım yapılmaya başlanmıştır. $\mathrm{Bu}$ durumda da geleneksel tarım yapan kadınlar küçük, orta ve büyük ölçekli çiftliklere emeğini satmak durumunda kalmıştır. Ücretli emeğe katılan kadının hane ve toplumda karar alma süreçlerine katılımını arttırabilmektedir. Bunun aksi de ücretsiz aile işçisi olarak çalışan kadınların karar alma süreçlerine etkisinin daha düşük olduğunu göstermektedir. $\mathrm{Bu}$ durum aslında şuna işaret eder; toplumsal cinsiyet eşitliği sadece istihdamdaki kadın erkek oranlarının eşitliği ile değil aynı zamanda kadınların refah ve güçlendirilmesine ne kadar etkili olduğu ile ölçülür. Erkeğin proleterleşme sürecine girmesi ile birlikte köylülük toplumsal farklılaşma sürecine girmiştir. Erkeğin ilk olarak ücretli emeğe katılması ile köylülük ve faaliyetlerinde yoğun emek olarak kadın emeği kullanılmıştır. Bir emek erkek emeği olarak kültürel olarak kodlanmışsa kadınlar işin tamamını yapmış olsa da erkeklere yardımcı olarak görülürler (Deere, 2005: 40). Feminizasyonu belirleyen iki önemli şey köylülükte kadınların artan sorumlulukları ve geleneksel olmayan tarımsal üretimde artan kadın emeği (Deere, 2005: 54). Bu her iki sürecin de kendi içinde ayrı ayrı gelişimleri vardır. Kadınların istihdam edilmeleri erkeklerden daha ucuzdur ve örgütlenme olasılıkları daha düşüktür.

İşgücü piyasasındaki cinsiyet eşitliği, cinsiyetler arasındaki marjinalleşmenin, sömürünün ve eşitsizliğin ortadan kaldırılmasına katkıda bulunabilecek en önemli faktörlerden biridir (Islam, 2016b: 157-158). Tarımsal yönetimin 
feminizasyonu karar verici olma açısından olumlu gelişme olarak algilanabilir. De Brauw vd. (2008: 348) her ne kadar kadınların girdilere, bilgiye ve yeni teknolojilere eriştiklerinde erkekler kadar eşit derecede verim üretmemeleri için hiçbir neden olmadığını söyleyerek piyasacılığı dayatsa da durum hiç de öyle değildir. Çünkü emeğin feminizasyonu ile birlikte yoksulluk da feminizasyon sürecine dahil olmuştur (Moghadam, 2005: 30-31). Küresel düzeyde, güvencesizliğin, kadın çalışmalarında tarihsel olarak mevcut olan belirli niteliksel özelliklerle birlikte, mevcut üretken süreçler için, kadınlar giderek stratejik bir emek havuzuna dönüşmektedir (Morini, 2007: 87). Tarımda çalışan nüfus oranı her iki cinsiyette zaman içerisinde düşmüş olmasına rağmen yine de kadınlar oransal olarak daha fazladır. Erkeklerin yarısı tarım dışı sektörlerde istihdam edilirken bu oran kadınlarda \% 35'tir (Pattnaik vd. 2018: 5-7). Tarımın feminizasyonu aynı zamanda tarıma ilişkin ve içkin sorunların da feminizasyonu anlamına gelmektedir (Pattnaik vd. 2018: 14-15).

Kapitalist üretim tarzının yeniden üretilebilmesi için, insanların ekonomik ilişkiler hiyerarşisinde çeşitli kategorilere dağıtılarak, yeterli miktarda emeğin olması gerekir. Eğer yeteri kadar emek yoksa birikim süreci engellenebilir. Bunun için de ülkelerin sınırları işçiler için bazen açılır kimi zaman da kapatılır. Fakat işçiler bir kez sınırdan geçtikten sonra hem yasalarca hem de ulus inşa süreçleri ile ötekilik konumuna dâhil edilirler. Böylece hem sinıfsal anlamda hem de etnik anlamında bir hiyerarşi oluşur. Bu süreç sadece dışarıdan gelen göçmen emeği için geçerli değildir aynı zamanda ülke içerisinde de ulusun dışında kabul edilen gruplar için de benzer şeyler geçerlidir. Burada aslında göçmen emeğinin gelmesi ile birlikte yerli emek daha yüksek ücret oranları ile karakterize edilen yeni işlere taşınabilir (Miles ve Brown, 2003: 130-131). Ya da taşındığı için de göçmen emeğine ihtiyaç duyulur. Örneğin İkinci Dünya Savaşı sonrasında İngiltere'de benzer şekilde gelişmeler olmuş ve göçmen olarak Karayipler ve Asya emeğine çağrıda bulunmuşlardır. Gelen emek belli sözleşme çerçevesinde bazen gelebildiği gibi bazen de kayıt dışı olarak da gelebilmektedir. Bu durum tamamıla kayıt dışı olmayabilir, görmezden gelinen ve yasal düzenlemelerin yapılmadığı bir kayıt dışılıktır. Ülkeler arası veya şirket-birey arasında yapılan anlaşmalarla belli iş kollarında göçmenler çalışmaktadır. $\mathrm{Bu}$ anlaşmaların hem kendileri hem de anlaşma metinlerindeki şartlar belli işçi profiline denk düşer. Fas ve İtalya arasındaki anlaşmaya göre belli sektörlerde ve belli sürelerde çalışmaya izin vermektedir (Zelinka, 2017: 41). Oysa İspanya'nın tarım başta olmak üzere belli sektörlerle sınırlandırdığı göçmen emeğini Kolombiya, Fas, Dominik, Moritanya, Ukrayna, Romanya ve Bulgaristan gibi ülkelerden sağlar. Fas ile yaptığı anlaşmada genelde kadınlar ön plana çıkmaktadır. Çünkü işverenlere göre kadınlar zarif ve hassas olan çileği toplamaya çok daha uygundur. Ayrıca kadınların daha uyumlu olduğu, rahatsızlık yaratma ihtimallerinin düşük olduğu ifade edilir (Enriquez, 2013: 128-133). Bu sebeple bu sözleşmeler iş gücünün feminizasyonuna veya etnikleşmesine zemin hazırlar. Sözleşmelerle veya sözleşme dışı olarak bir ülkede bulunan ve tarımda çalışan göçmen emeği kırsal bölgelere dağ 1 lmış bir şekilde toplu halde ve toplumun diğerlerinden izole şekilde yaşarlar. Bezen eğitim, etkileşim ve entegrasyon gibi seçenekler bulunsa da sosyal entegrasyon buna izin vermez. $\mathrm{Bu}$ emek hareketliliği ayrıca çok kırılgandır, çünkü ülkelerdeki ekonomik sıkıntıların faturaları bunlara mal edilerek ilk gözden çıarılacak kişilere dönüşürler. Uzun süre anlaşma veya belgesiz olarak bu hiyerarşiler içerisinde yer alan göçmen emeği belli fenotip özelliklerine atıf yapılmaya başlanır böylece emek etnikleşme sürecine adımını atar. Bazen tarım dışı sektörlerde kullanılan göçmen emeği de etnikleşme sürecini hızlandırabilir. Göçmenleri belli iş kollarına sıkıştırmak ve belli pozisyonlara onları layık görmek emeğin verimliliğini düşürdüğü gibi yeteneklerini sergileyememelerine ve kendilerini kisitlayarak, kendilerine yabancılaşmalarına sebep olur. Bazen de bir gurubun hangi aşamada göçmenlere dâhil olarak emeğini sunduğu da önem taşımaktadır. İlk göçmen emeği bir sektör içine ilk yıllarda dâhil olduğunda bu grup kendi içinde hiyerarşi oluşturur ve belli iş kolunda hâkim etnik grup olurlar. Aynı sektöre sonraki yıllarda dâhil edilen bir başka göçmen emek bu sefer var olan hiyerarşi ile karşılaştığından uzun süre niteliksiz işlerde ve ilk göçmen grubun yapmakta istekli olmadığı işlerde çalışmaları sonucunu doğurur.

Göçmen emeğinin hem genel hakim etnik yapı üzerinden hem de farklı göçmen etnik unsurlar arasında etnik durumlara atıfla bazı karakter atamaları yapılır. Örneğin Almanya'daki Almanlar diğer etnik unsurları tembel, kirli, yavaş, disiplinsiz, kazaya eğilimli gibi görebilir. Başka bir boyutu ile de her iki göçmen emeği bu durumları birbirine karşı da söyleyebilir. Müslümanların domuzu kirli bulması ve domuzla ilişkilenenleri bu bağlamda değerlendirmesi, Güney Afrika'da siyah işçiler için söylenen "onları ormandan çıkarabilirsin fakat ormanı onlardan çıkaramazsın" ifadesi (Sautman ve Hairong, 2016: 2151) ya da Çin'in çok kalabalık olmasına vurgu yapılarak orada bir kişini ölmesinin önemsiz olduğunu ifade etmekte gizli ve açık bir etnikleştirmeye işaret eder. $\mathrm{Bu}$ ifadeler de emeğin etnikleşme sürecinin yaratılmasında ön ayak olarak benzer sömürü koşullarına sahip grupların sömürüye karşı ortak mücadelesini de kesintiye uğratır. Ulusun hakim unsuru bazen göçü ve dışarıdan ithal edilen emeği çok kötü bir şey olarak göstermeye 
ve gelen herhangi bir grubu ulusu inşa eden etnik unsur üzerinden tanımlama eğilimi gösterir bu da etnikleşmeyi mümkün kılar. Her ne kadar ırkçılık ideoloji ile çok güçlü bir ilişkiye girse de işlevsel olması bakımından üretim tarzında zorunlu olarak çelişkili bir fenomendir. $\mathrm{Bu}$ sebeple göçmen emeğinin kullanılması ve ırkçılık arasında diyalektik bir ilişki vardır. Şüphesiz Sovyetler Birliği'nin dağılması ile birlikte küreselleşme hız kazanmıştır. Böylece sermaye ve emek hareketleri gittikçe daha uluslararası hale gelmiştir. Ulusun sınırlarının sermayeye engel teşkil etmemesi için belli ekonomi politikaları ile sınırsız bir dünyaya gidişat söz konusu iken aynı şey emeğin hareketliliği için söz konusu olmamıştır. Dolaşım süreci kapitalist üretim tarzının merkezi dinamiği sermaye birikimi tarafından belirlendiği için emeğin ve sermayenin dolaşımında bu farklılık belli ölçüde anlam kazanmaktadır. Emek gücünün uluslararası dolaşımı sermayenin dolaşımından farklı olarak mekânsal bir hareketlilik içerir; emek gücü insanların kapasitesidir, fiziksel bedenlerden ayrilamazlar. Fakat ulus, devlet dünyasında potansiyel olarak uluslararası hareketsizliğin bir faktörüdür (Miles ve Brown, 2003: 10). Bu açıdan yukarıda her ne kadar göç ve ırkçılık arasındaki ilişki ekonomik bir ilişki olarak ifade edildiyse de bazı durumlarda ekonomik bir ilişki olmaktan uzaklaşarak neo-faşist iktidarların günümüzde giderek kurumsallaşması bağlamında da bu olgu değerlendirilebilir.

Sermayenin göç üzerinden emeğe dayattığı esneklik ve hareketlilik olağanüstü bir yersiz yurtsuzlaşma dinamiği yaratır. Sınırların çöküşü göçmen emeğini belirlemiyor, göçmenler sınırların çöküşünü belirliyor. Böylece kapitalist kontrolün mekânsal istikrarı tehdit edilmektedir. Bu sebeple sermayenin karşı karşıya kaldığı görev sürekli olarak sınırları yapılandırmak, emekçi nüfusu yeniden bir mekâna bağlı hale getirmek ve toplumsal mekânın sabit boyutlarını yeniden inşa etmektir (Hardt ve Negri, 2011:145-146). Bu politikalar ve süreç emeğin etnikleşmesinin sosyal, ekonomik ve politik güçlere bağlı olarak değiştiğini göstermektedir (Bonacich vd. 2008: 343). Uluslar belli ırk grubunu kendi üyeleri olarak görürler fakat diğer etnik unsurlar bu üyelikten dışlanır. Kategori olarak alta itilen bu insanlar sistematik olarak eşitsiz muamele görürler. Ulusun bu şekilde kurgulanması sebebiyle kapitalizm bunu araçsallaştırarak kendi yararına hem yeniden üretir hem de kullanır. Alt grupların emeğini daha etkili bir şekilde sömürmek için de etnikleşme öne çıkmaktadır. Bu durum da renkli insanların kapitalist sistemde orantısız bir şekilde sömürülmesi sonucu ortaya çıkmaktadır. Emeğin etnikleşmesi ile kapitalistler daha düşük ücretle işçileri istihdam ederek kârlarını maksimize ederler. Dahası kapitalistler renkli insanları daha aşağı koşullar altında yaşamaya ve çalışmaya zorlar (Bonacich vd. 2008: 343).
Emeğin etnikleşmesi işçileri ayrıca sınıf ve cinsiyet olarak da böler. Bütün kadınlar cinsiyetlendirilmiş bir iş bölümü ile karş1 karşıya kalmakla birlikte bu kadınlar arasında renkli olanlar daha zor işlerde ve daha kötü çalışma koşullarına sahiptirler. Beyaz kadınlar erkeğe oranla eşitsiz ilişkilere sahiptir fakat etnikleşme süreci ile birlikte çalışma koşullarının en kötülerine sahip olmaktadırlar. Bu sebeple ırk, toplumsal cinsiyet ve milliyetçilik üretimleri sürekli olarak kesişirler (Murji ve Solomos, 2005: 1415). Siyah hemşireler kadın hastalıkları alanında veya yoğun bakım ünitelerinde yoğunlaşması (Zaman, 2010: 167) her iki bağlamın kesişimine vurgu yapar. $\mathrm{Bu}$ sebeple rrk ve cinsiyetin sosyal yapıları tarihsel ve sosyal coğrafyacıların daha fazla ilgisini hak etmektedir (Jackson, 1992: 204-205). Örneğin Amerika ile imzalanan Bracero tarım işçiliği anlaşması göstermiştir ki işçiler daha etkili bir şekilde sömürülebilmeleri için etnikleştirmeleri gerekmektedir. Bu sadece iki ülke arasında böyle işlemez, ülke içi ilişkilerde de böyledir. Steinbeck'in (2018) Gazap Üzümlerinde bahsettiği emek süreci Oklahoma'dan Kaliforniya'ya göç eden emekçilerin nasıl aşağılandığı ve etnikleşmeye dahil edilerek sömürüldüğü etkili bir şekilde anlatılmaktadır. Burada da beyaz olmayanlar beyazlara göre daha iyi sömürülebileceğinden dolayı etnikleşme beyaz kapitalistler tarafindan icat edilir. Ayrıca beyaz işçiler kendi çıkarları için ırkçı-cinsiyetçi yollar kullanırlar. Her iki durumda da bundan faydalanan sermaye olmaktadır. Etnikleşme emek sistemleriyle ilgisi olmayan çok yönlü kültürel ve psikolojik kökenlere sahip olmasına rağmen sömürenler açısından yararlı bir araçtır. $\mathrm{Bu}$ sebeple piyasa, emeğin kullanımı için kurumlar ve kurallar geliştirir. Özellikle göçmen emeğinin belgesiz olduğu durumlarda bundan yararlanılarak etnik bir işçi kastı oluşturulur. Göçmen emeği barbar, eğitimsiz ve yasal haklardan mahrum olarak görüldüklerinden de beyaz bir vatandaş kadar kazanmamaları gerektiğine inanılır. Aslında etnikleşme burada araçsaldır, çünkü sömürünün sayısız biçimine bürünür. Kapitalist sistem ataerkilliğe dayanan ırkçı-cinsiyetçi eşitsizliği üreten bir sistemdir. Bu açıdan da etnik küresel emek teorisinin geliştirilmesi gerekir (Bonacich vd. 2008: 352-353). Burada cinsiyet ve rrkla başa çıkmak için sınıfla başa çıkmak gerektiği itirazı yapılabilir fakat bunun yapılabilmesi için hâkim ulusun işçi sınıfının beyaz ırkçı ve cinsiyetçi kimliğinden uzaklaşması gerekmektedir (Bonnett, 1998: 335-336).

Etnikleşme sürecinde etnik farklılıklar doğallaştırılır, dışlamalar normalleştirilir böylece ötekine yapılan her muamele meşrulaşır. Buna rağmen hükümetler yasalar yolu ile bunu yeniden üretir ve sürdürürler. Göç yasaları emeği belli hiyerarşilere yerleştirir, ulusu tanımlar, ulusun dışında olanları yokluğa mahkûm eder. Böylece emek hareketliliği; milliyet yolu ile yerli-yabancı arasındaki sosyal ilişkiler etnikleşir. Bu yapı ise 
işçilerin emeklerini sattıkları koşulları belirler; işçilerin ücretleri, statüleri ve terfileri etnik ilişkilere dayanır (Carter vd. 1996: 136-137). Bu açıdan etnikleşme hem analitik hem de sezgisel bir araçtır. Nitelik olarak tanımlanan ve bu şekilde sınıflandırılan insanların hizmet ve kaynakların tahsis edilmesi sürecinde bazı grupların bu sürece dahil edilmesi ve hariç tutulması için kriterlerin oluşturulmasına temel olur (Teelucksingh, 2006: 4). Yukarıda belli kısımlarda etnikleşme süreci beyaz ve renkli arasındaki ayrım üzerinden ifade edildi. Fakat bu her zaman böyle olmak durumunda değildir. Sermaye sistemi etnikleştirebileceği bir "siyah" bulamadığı durumlarda mutlaka bir "beyazı" "siyahlaştırır". Beyazların içindeki beyazları "diğer" kategorisine dahil ederek bunu yapar; hatta nüfus sayımlarında gerçek anlamda "diğer" kategorisi koyar. Hitler Almanya'sında Yahudiler o kadar görünmezdi ki Yahudilere sarı bir yıldız işareti takarak onları işaretlemişlerdir. Fakat burada unutulmamalıdır ki etnikleşme her zaman beyaz tekelin elinde olmuştur. Kanada her ne kadar hem göçmenler açısından hem de kendi ulusu içerisinde çok kültürlülük ile övünse de ciddi anlamda emek sömürüsü için emeği etnikleştirir. Çünkü çok kültürlülük politikası liberal sermaye sistemi ile iç içedir. Ev işçiliği, hazır giyim, endüstri ve sözleşmeli çiftlik gibi işler bu ülkede etnikleşmiştir (Teelucksingh, 2006: 6). Etnikleşmenin önemi özellikle refah devletlerinde emek hareketliliği ve heterojenleştirme arttıç̧a ivme kazanmaktadır (Faist, 1995: 244-245). Emeğin etnikleşmesi diğer birçok durumunda da etnikleşmesine sebep olmaktadır. Yoksulluğun etnikleşmesini de beraberinde getirir. Yoksul bir etnik grup kendi mahallesini oluşturur, eğitim ve sağlığa erişimde firsat eşitliği elde edemez, ölüm oranları etnikleşen gruplarda daha fazladır. Etnikleşme onların ayrımcılığa uğramasına sebep olur, her ayrımcılık da onları daha da etnikleştirir, akıl ve ruh sağlıkları bozulur (Galabuzi, 2005: 40-41). Böylece kronik bir emek gettosu oluşur. Düşünce de etnikleşerek farklılık sürekli olarak konumlandırılır ve kimlik inşa edilir (Murji ve Solomos, 2005: 8). Etnikleşmenin nasıl ki toplumsal cinsiyet bağlamı varsa aynı zamanda sınıf bağlamı da vardır (Krahn, 2014: 52). Etnikleşme sürecinin politik ekonomi yönü bunu gerektirmektedir (Gabriel, 1994: 2021). Bu açıdan bu tür durumları analiz etmek için kesişimsel bir analiz gerekmektedir. Kesişimsel analiz de cinsiyet, etnikleşme, göç ve iş gücü piyasalarının birlikte değerlendirilmesini içerir.

\section{CAAY TARIMINDA EMEĞİN FEMINIZZASYONU}

Şimdi Türkiye'deki Çay bölgesindeki feminizasyon sürecinin nasıl üretildiğini ele alabiliriz. Fakat buradaki feminizasyon süreci yukarıdaki kuramsal kısımdan faklı olarak kullanılan emek ücretli değildir. Bu açıdan da geleneksel formunu belli kısımları hala sürdürmektedir. İş gücü ekonomik sebepli bir olgu olduğu için bu ekonomik koşulların tarihselliği emek hareketliliğine neden olmaktadır (King, 2012: 16). Fakat bu konuda yapılan çalışmalar da olgunun tarihsel seyri bir eksiklik olarak karşımıza durmaktadır (Kaya, 2009: 48-49). Bu sebeple çayda kullanılan emeğin bu günkü koşullarını anlamak için tarihsel bir yolculuk yapmak gerekecektir.

Osmanlı'nın son dönemlerinde Doğu Karadeniz kıyı kesimlerindeki erkek işgücü döngüsel olarak diğer komşu ülkelere hareket etmekteydi (Hann ve Hann, 2012: 24-25). Bu dönemde Rusya'nın önemli bir hedef ülke konumunda olduğu anlaşılmaktadır. 1931 yılında yapılan bir araştırmaya göre (Obolensky-Ossinsky, 569) Osmanlı'dan Rusya'ya (1878-1880) elli binden fazla kişi emek hareketinde bulunmuştur. Yine benzer şekilde Rusya'ya ilk giden öncü gruplar sonrasında önemli ölçüde erkek, emeğini Rusya'ya taşımıştır. Bu harekete katılanlar başlangıçta topraksız köylülerden oluşmakla birlikte çoğunlukla hedef bölgede taşçılık ve rençberlik işleriyle uğraşmaktaydı. Tarım alanlarında tütün çiftliklerinde ve alt yapı alanlarında çalışmaktaydılar (Sarı, 2014). Ekim Devriminden sonra ve İkinci Dünya savaşı ile birlikte Almanların Polonya'yı işgal etmesiyle bölgenin erkek emeğinin hareketliliği sona ermiştir (Biryol, 2017: 65-69). Bu dönemde bölgenin halkı geçimini hayvancılık, balıkçılık ve kendi bahçelerinde özellikle mısır ve fasulye ekimi yaparak sağlamaktaydı. 1930'lu yıllarda bölge halkı ülke içi emek hareketliliğine gurbete gitme olarak katılmaya başlamıştır. 1960'larda çay, bölge ekonomisine katılsa da yeterli görülmediği için bu hareketlilik devam etmiştir. Erkek emeğinin elde ettiği ekonomik kazanımlar birçok köy, kaza ve kasabanın çehresini değiştirmiştir. Birçokları var olan evlerini iyileştirmiş veya yeni ev almışlardır bir kısmı da tarım arazisi satın almıştır (Bay, 2017: 50).

Çay bitkisi her ne kadar 1957'de uygulamaya geçse de aslında 1920'li yıllarda Batum'dan çay bitkisi getirilerek denemeler yapılmaktaydı. Halkın bu yeni bitkiyi benimsemesi oldukça sancılı geçtiğinden başlangıçta çay bitkisini tarlalarına ekmeleri için belli destekler verilmekteydi. Bu yıllarda erkekler gurbette olduklarından mısır tarlalarının çay alanına dönüşmesi kadınların öncülüğünde ve onların emekleri ile gerçekleşmiştir. Mısır'dan çaya geçiş süreci oldukça sancilı olmuştur. Türkiye İkinci Dünya Savaşına katılmasa da her ihtimale karşı gıda stoku yapmaktaydı. Bu sebeple tahıl fiyatları konumuz açısından mısırın fiyatı artmıştır (Zihnioğlu, 2008: 5-6). Mısırın fiyatı artınca çay bahçelerinin yaygınlaştırılması da yavaşlama sürecine girdi. 1940 yılında Samsun'da mısır hasadı verimli geçince çay bölgesindeki mısır açığı karşılığında üreticilerle anlaşma yapılmıştır. Bu anlaşmaya göre tarlaların bir dönümünün 
çay bahçesine dönüştürülmesi halinde yüz kilogram mısır verilmesine karar verildi. Bu destekle birlikte bölgede çay alanları yeniden genişleme sürecine girmiştir. Çayın öncesi ve sonrasını bilen 89 yaşındaki bir katılımcı bu süreci tüm açıklığı ile ifade etmektedir:

\begin{abstract}
"Babam ben ufaktım 12 yaşındaydım. Babam gurbete gitti. $O$ sene de misir az oldu yetmez bize diye gurbete gitti. Seneyi dolaşamayacaktık o misırla. O zaman da hiçbir şey yok. Bundan dolayı gurbete çıktı. Bu oda kadar bir yeri bir devletin desteğiyle çaylık yaptık, ahır gübresiyle besledik onu filizlendi. Annem onları topladı verdi benum koluma. Köyden annem verdi çayı bana yürüyerek oradan (30 km'lik bir mesafe) bu köye geldim çayı satmaya, şimdiki caminin yanındaki medresenin altında alım yeri vardl. Anam dedi bana ki sende git peşin para ile çaylart sat da gel dedi bana. Geldim burada bana 2,5 kuruş verdiler gittim verdim onu anama. Anam gitti Boya'ya (belediye ismi-şimdiki adı Yolbaşı) tucanlar (dükkân) vardı, kumanya aldı, içă̆l $(i c ̧$ yağl) aldı, şeker aldı baya bir para yani. Sonra babama yazdik mektup dedu ka ki: Baba ister izin ver istersen verme falanca yeri de çayluk yapacăğz. Sen gurbete 3 aydır bu kadar para göndermedin bize bak bir avuç çaydan aldık bu kadar para. Misır bahçesini çay yaptık. Sonra babam geldi gurbetten martlarda geldi, gene o çaydan diğer elde de topladık oradan evi baya çevirdik, geçindirdik. Babam ondan sonra geldi dedi ona anam, daha gurbete gitme çay edelum, o kadar çaydan bir sürü para aldik sen bir sene de o kadar para edemiyordun. Öyle başladık çay yapmaya ettuk ettuk iyi yerleri fazla yapmaduk, misır veren yerleri, diğer yerleri yaptı. Babam da gitmedi. Baktuk çay çok iyi para bulduk öyle olunca başladık iyi yerlere de yapmaya. Ondan sonra yapa yapa evin ahır altına kadar dayandık, her yeri yaptık, küçük bir bahçe bıraktık. Ondan sonra ne babam gurbet gördü, herkes ev etti, konak yaptı, zengin oldu hala daha böyle gidiyor. Babam İmit Karamürsel tarafina giderdi. Bă̆ bahçe kazard, inşaatta çalışırdı. Kaynatam da giderdi ben gelince (bu köye evlenince) çay ilerlemişti gitmekten vazgeçti" (İG-89 yaşında-Kadın). (Öksüz, 2019: 73).
\end{abstract}

$\mathrm{Bu}$ ifadeler ortaya koymaktadır ki hem çay tarımı öncesinde kadının ev içi emeğinin bir uzantısı olarak tarlalar görülmüş ve çay tarımının bölgeye yerleşmesinde de kadın emeği kullanılmıştır. Çay tarımı öncesindeki yoksulluğun ne kadar çarpıcı olduğu sıklıkla bölge halkı tarafından ifade edilir. Bu dönemde kadınlar üretmiş oldukları ürünleri şehir merkezine giderek satmaktaydı ve bunun karşılığında üretmedikleri ürünleri satın almaktaydılar. Hatta hayvanların yalağını hazırlamak için tuza verebilecek paraları olmadığından deniz suyunu evlerine taşıyarak yalak hazırlamaktaydılar. Çayın bölgeye yerleşmesi ile birlikte işgücü piyasası ve belgedeki demografik yapıyı etkilemiştir. Çay öncesinde bölgenin dağlık alanlarında hayvancılık ile uğraşan ailelerin ekonomik durumu nispeten iyi iken, çayın kıyı bölgelerinde yetişme imkânı bulmasıyla giderek kıyı bölgeleri ekonomik olarak iyileşme yaşamış ve dağ kıyı arasındaki dengeler tersine dönmüştür (Hann ve Bellér-Hann, 2012: 83-84). Bu durum da bölge ve ülke içi göç sonucunu doğurmuştur. ÇAYKUR'un kurulması ile birlikte gurbete giden erkeklerin bir kısmı geri dönmüş ve fabrikalarda işçi olarak çalışmaya başlamışlardır. Devlet böylece bölge ekonomisini geliştirmiş ve nispeten köylülüğü dönüştürmüştür. $\mathrm{Bu}$ örnek ekonominin yukarıdan aşağıya geliştirilmesinin bir örneğidir (Keyder, 1987: 155). Devletin çay üreticisi yaptığı köylüler bu konumlarını muhafaza ederek emek piyasasına da iş̧̧i olarak dahil olmuşlardır. Yukarıdan aşağıya geliştirilen bu sistem salt ekonomik değildir aynı zamanda ideolojiktir. Bölge insanının ekonomik olarak devlete bu şekilde bağlanması hem sınıf mücadelesini engellemiş hem de var olan ideolojik yapının bölgede yerleşmesine neden olmuştur. Bölgede devlete kutsallıkla atfedilen milliyetçilik çay sanayisindeki üretim ilişkileri rolüyle toplumsallaşmış bir milliyetçiliktir. Böylece devletçi milliyetçiliğin kurumsal dili aile yapısının içine işlenmiş ve toplumsal cinsiyet eşitsizliğini yeniden üretmiştir. Milliyetçilikte millet bir aile olarak betimlenir ve devlet de bu ailenin reisi olur (İnal, 2018: 14-15). Bölge halkının çay öncesi ve sonrası hafizası arasındaki zitlık Cumhuriyet meyvesi olan çaya ve onun ürettiği yapıya adapte olmalarını kolaylaştırmıştır.

1950'lerde Türkiye genelinde serbest piyasa ile başlayan iç göç hareketi giderek artar ve 1980'lere gelindiğinde önemli bir nüfus bölgeden göç eder. 1950 ve sonrasında büyükşehirlere en fazla göçün yaşandığı bölge sıralamasında ilk sırada Karadeniz Bölgesi yer almaktadır (Özbay 2017: 137). Bu yıllarda ÇAYKUR'un fabrika sayısı 45'e kadar çıkmakla birlikte özel sektör piyasaya dahil edilmiştir. Özel söktürün yanında ÇAYKUR'da pazarlama, nakliye bölümü de özelleştirilmiştir. Bölgede yaşanan bu demografik değişmelere 1990'lı yıllarda Sovyet Birliği'nin dağılması ve oradan hareket eden nüfusların emekleri bölgedeki dönüşümün imdadına yetişmiştir. İşte bu aşama aslında ve özellikle de günümüze yaklaştıkça yoğunluğu artan işgücünün etnikleşmeye başladığı döneme işaret etmektedir. Bölge içindeki az topraklı/topraksız köylüler emeğini bölge içinde satarak geçimini sağlamaya çalışmıştır. Bunun bir yolu da çay tarım alanlarında yarıcılık yapmak olmuştur. Tek başına yeterli olmayan bu yeni gelir kapısı karşısında geliri çeşitlendirmek için fabrika veya diğer işlere eş zamanlı olarak yönlenmişlerdir. Çünkü tarımsal üretimden elde edilen gelirin payı toplam gelir içinde düştükçe tarımsal üretim sürdürülemeyebilir. Bunun sonucunda tarım tamamen bırakılır, böylece aile üretim birimi olmaktan çıarak tüketim birimine dönüşür (Özbay, 2017: 46). Bu sebeple de tarımın payı toplam gelir içerisindeki oranı düşünce bölge halkı göç etmeye başlamıştır. Bunun yanında çay tarımı 
başka bir işle uğraşabilmeyi mümkün kılmaktadır. Çünkü çay diğer tarım ürünleri gibi sulama, ilaçlama ve hassas bir bakım gerektirmemektedir. Ülke içi göçün ilk zamanlarında çay hasadı aile emeği ve imece usulü yapılırken sonraki zamanlarda bu işler için ücretli emek kullanılmıştır. Eğitim ve diğer sebeplerle şehir merkezine göç etmiş olan aileler de yaz dönemlerinde çay hasadını sürdürmeye davam etmişlerdir. $\mathrm{Bu}$ durum kent içi döngüsel emek hareketliliğine göndermede bulunmaktadır, bunun yanında bir kavram olarak part time köylülük de denmektedir (Kulaçoğlu, 2016: 224). Bir diğer olgu bölgedeki miras hukuku ve demografik göstergelerdir. Ortalama yaşam süresinin bu günden daha kısa olduğu dönemlerde miras ancak hane reisi baba öldüğünde gündeme gelmekteydi. Fakat yaşam süresinin uzaması ile birlikte hane halkları daha uzun bir süre geniş aile formunda kalmayı sürdürmüşlerdir (Özbay, 2017: 56). Geniş aile formundan çıkış yolu olarak da ailenin tüm erkek üyelerinin evlenmesi ile birlikte araziler miras üzerinden bölünmüş̧ür. Bu yolla da araziler hızla küçülme yoluna gitmiştir. $\mathrm{Bu}$ bölünme ile ortaya çıkan çekirdek aileler tarım gelirleri ile geçinemez duruma gelmiştir.

1986 yılında devletin sektördeki tekeli liberal anlayışlar çerçevesinde kırılarak piyasaya özel sektör girmeye başlamıştır. Bunun sonucunda çayın ekilebilir olduğu düşünülen çalılık, fundalık ve ormanlık alanlar çay bahçesine dönüştürülmüştür. Fakatçaybitkisibelliekolojikalanlardışındayetiştirilemediğinden bu genişleme süreci kısa sürmüştür. Neoliberal politikalar ve demografik değişimler sebebiyle kırsaldaki emek aileden özgürleşmiştir. Fakat kentsel alanlarda emek aileden kopsa da birey aileden azade olamamıştır. Kentlerde yaşam biçimi olarak çekirdek aile formu yaygın olsa da ilişkiler geniş aile formunda devam etmektedir (Özbay, 2017: 57-59). Bu ilişkileri örgütleyen şey de geçmişte sahip oldukları geniş topraklardır ve burada altta yatan bağlam da toprak mülkiyetidir. Bölge nüfusunun eğitime katılma oranlarının artması ile birlikte de bireyin bağımsızlaşmasına ve aile büyüklerinin otoritesinin sarsılmasına sebep olmuştur (Özbay, 2017: 63-64). Demografiye yönelik bu değişimleri Yüceşahin (2009: 15) belli alt kategorilere ayırır; bölge doğum ve ölüm hızlarının yüksek olduğu 1935-1945 yılından 2000'li yıllara değişim göstermiştir. Çay bölgesi bugün düşük doğum ve düşük ölüm oranları üzerinden karakterize olmaya başlamıştır (Aydın vd. 2018: 35).

Erkeklerin gurbete (Rusya) gitmesi, erkeklerin sorumluluklarını da kadınların yüklenmesine sebep olmuştur. Nitekim Rusya'ya giden erkekler orada üst sınıfa hitap eden pastacılık mesleği ile uğraşmış ve dil öğrenmişlerdi. Zaman zaman memleketlerine dönseler de takım elbiselerle yaylalarda herhangi bir tarım ve ev içi emeğine katılmayarak dolaşmışlardır (Biryol, 2017: 6). Çay tarımının bölgeye yerleşmesi ile birlikte erkekler fabrikalarda çalışmaya başlamış ve çay tarımının ihtiyaç duyduğu emek de kadınlar üzerinden sağlanmıştır. Zaten gurbete giden erkekler de belli dönemlerde memleketlerine döndüklerinde tarım işleriyle uğraşmamaktaydılar. Böylece ev içi ücretsiz emek ile kamusal alandaki tarım emeği arasında organik bir ilişki kurulmuş emek feminizasyon sürecine dahil olmuştur. Gürcülerin gelmesi ile birlikte doğrudan emek etnikleșmeye uğramıș değildir. Çünkü çay bölgesindeki katı toplumsal cinsiyet rejimi ve tarla ile kadın arasında kurulan organik bağ sebebiyle kopuş sanc1lı olmuştur. Bu organik bağ kadının duygulanımsal emeğini de içerir. Duygulanımsal emek (maddi olmayan emek) birçok üretken işin merkezinde yer alsa da bu emeği üreten kadınlar yine de tabi konumdadır (Hardt ve Negri, 2020: 126). Tarımsal emek kadınlar için gerekirse güneşin doğuşundan batışına kadar sürer. Bu sebeple arada kurulan organik bağ işgücü fikrini tamamen yok eder ve kadının hayatının tüm alanlarına sızar. Böylesi bir sistemde kadın ücretsiz emeği varken ücretli Gürcü emeği kullanmak kınanacak bir durumdur. Kadınlar burada bazı durumlarda Gürcü emeği kullanmak istemelerine rağmen toplumsal baskıya yer vermemek için belli süre kendileri hasadı yapmaya devam etmişlerdir. Gürcü emeği kullanmak için toplumu ikna edecek bir bahaneniz olması gerekir. Özellikle ekonomik durumu çok da iyi olmayan kişilerin ücretli Gürcü emeği kullanması var olan toplumsal yardımlaşma ağlarını da yıkıma uğratmıştır. Gürcü emeğinin kullanılması kişinin parası olduğu ve artık yardıma ihtiyacı olmadığı algısını üretmektedir. Gürcülerin yaygınlaşması ile birlikte özellikle büyük şehirlerde yaşayan ailelerden emekli yaşlı erkeğin gelmesi ile birlikte Gürcüler üzerinden çay hasadı yapılabilmektedir. Bazı durumlarda Gürcü emeğini kullandığı halde çay hasadı döneminde memleketlerine dönen kadınlar çay hasadına dâhil olmamakla beraber tarlalarında mısır, fasulye gibi aile bütçesine katkı sağlamak adına emeğini kullanmaktadır. Geniș aile formunun olduğu ailelerde çay hasadında Gürcü emeğinin kullanılmasına büyükler karşı çıkmaktadır. Fakat bu büyüklerin aşırı yaş ile otoritelerini kaybetmeleri veya ölmeleri ile birlikte bu aileler de Gürcü emeğini kullanmaya başlamıștır. Tüm bunlara rağmen Gürcü emeğini kullanmak istemeyip direnen aileler vardır. Onları buna motive eden şey salt ekonomik değildir. Nasıl ki yaşı kadınlar mutfaktaki konumunu kaybetmesi ile birlikte otoritesini de kaybedeceği gibi çay hasadında Gürcü emeğini kullanması da aile içerisinde otoritesini sarsabilmektedir. Çünkü çay hasadında her ne kadar kadın emeği ücretsiz olsa da aslında kadının elinde ekonomik bir güçtür. Çünkü kadının emeği olmadan erkek bu çayın gelirine kavuşamaz. Bu açıdan da kadının pazarlık gücünü arttırmaktadır. Fakat Gürcü emeği kullanılırsa iş doğrudan erkek işine dönüşmekte ve tüm yönetim erkeğe kalmaktadır, bu haliyle 
de kadının hem emeği hem de sürece müdahale etme hakkı elinden alınabilmektedir. Gürcü emeğinin ortaya çıkması aile ve komşuluk bağlarını çözmüş ve bireyselleşmenin artması ile birlikte imece usulü ortadan kalkarak yardımlaşma kavramının yerini Gürcü emeğine bırakmıştır.

Emeğin ücretsizlik üzerinden feminizasyonu sadece belli işlerin cinsiyetlendirilmesi ile gerçekleşmez aynı zamanda işin yapılış biçimi de feminizasyona uğrar. Çay hasadındaki kadınların çay toplama ve taşıma süreci de cinsiyetlidir. Bir erkeğin kadın kadar çay toplayabilmesi istenen bir durum değildir. Çay toplama işine kadınlar daha yatkın görülür. Ayrıca çay taşıma işi iplerle sırtta ve belden aşağıya doğru eğilmiş şekilde taşınıyorsa bu taşıma biçimi kadınsaldır, fakat aynı kilo çay, ipsiz ve omuzların üstünde dik taşınıyorsa bu da erildir. Bu açıdan bir kadın erkek gibi taşıyorsa güçlüdür fakat bir erkek kadın gibi taşıyorsa da güçsüz olarak algılanır. Bu durum sadece çay tarımı sonrasında gelişen bir süreç değildir. Erkekler fasulye ve mısır dikme, hayvan gübresi taşıma ve ürünleri hasat etme gibi süreçlere de katılmamaktadır. Ortaya konulan emek ve üretim değeri kadınlarda fazla olmasına rağmen önemi yoktur. Fakat emeğin arkasında yatan bu feminizasyona rağmen iş kamusal alana yani çay alım yerlerine vardığında erkek ve erkeklik orada devreye girerek erkek, emeğin arkasında yatan tüm süreci sahiplenir. $\mathrm{Bu}$ açıdan alım yerleri erkekliklerin sergilendiği gösteri alanına dönüşür. Ayrıca eşi tarafından terk edilmiş ya da alım yerinde erkeklik sergilemekten vaz geçen erkekler olunca kadınlar alım yerine gidebilmektedir. Kadının oradaki erkek alanındaki varlığı da diğer erkekleri rahatsız eder. Bu durum karşısında orada bulunan kadına yenge adamın yok mu? diye sorulur. Bu soru emeğin arkasındaki tüm süreci gizler ve erkek lehine dönüştürür. Çünkü alım yerindeki kadın oraya gelene kadar sabah beşte kalkıp çay hasadını yapmış, 50-60 kg çayı dik yokuşlardan taşımış ve kamyona yükleyerek alım yerine kadar getirmiş̧tir. Ücretsiz feminizasyon sürecindeki bu arka planın ücretli piyasadaki karşılığı da kadının emeğinin görünmezliği ve daha düşük ücret ödeme pratikleridir. Kadının sadece emeğine (duygulanımsal emek dahil) değil aynı zamanda ürettiği artı değere de erkek aile adına el koymaktadır. Bu açıdan da kapitalist sistemin artı değere el koyması süreçleri ile bütünleşiktir.

\section{5. ÇAY TARIMINDA EMEĞİN ETNIKLEEŞMESI}

\subsection{Tarihsel Arka Plan}

Çay tarımında emeğin Gürcüler üzerinden etnikleşme süreçlerini anlamak için Türkiye-Gürcistan arasındaki ilişkilere, Gürcistan'ın bağımsızlık kazanması ve liberal ekonomiye geçişi ile birlikte değerlendirmek gerekmektedir. 1921 yılında tarihsel, kültürel ve kolektif hafizadan uzak salt pozitivist fiziki unsurlar göz önüne alınarak Gürcistan-Türkiye sınırı çizilmiştir. Böyle bir anlayış her iki ülkenin var olan bağlarını tam olarak koparmasa da kesintiye uğratmıştır. Ulus-devlet ideolojisi ile çizilen sınırlar tarihsel bağ açısından var olan döngüsel hareketin uluslararası bir hareket olmasına neden olmuştur. $\mathrm{Bu}$ durum sadece sınırların çizilmesi ile ilgili değildir aynı zamanda 1937 yılında Sovyet Birliği ile Türkiye arasındaki anlaşmazlıklar sınırın kapatılması ile sonuçlanınca var olan bağlar iyice gevşemiştir. 1937'den 1989 yılına kadar toplam 52 yıl süreyle kapalı kalan sınırın ardında her iki ülke de kendi ulusuna karşı propagandalar yapmıştır. Türkiye komünizm düşmanlığı ile ideoloji üretirken, Sovyet Rusya'sı diğer ülkeleri köleleştirici ve karanlık ülkeler olarak resmetmiştir (O'Loughlin vd. 2007: 151152). Birliğin çökmesi ve bağımsız ülkelerin ortaya çıkması ile birlikte Türkiye gerek mesafe açısından yakın olması gerekse vize kolaylıkları sebebiyle önemli bir hedef ülke konumuna yükselmiştir. Türkiye enformel sektörü hala yeterinde denetleyemediğinden dışarıdan gelenler rahatlıkla bu sisteme entegre olabilmektedir. $\mathrm{Bu}$ sebeple bavul ticareti mümkün olmuştur (İçduygu, 2004; Kaşka, 2006). Daha güncel olarak 2006'da Türkiye ile Gürcistan arasında tek taraflı 90 gün vizesiz hareket izni döngüsel emek hareketliliğinin giderek yoğunlaşmasına sebep olmuştur. 2011 yılında ise 90 gün serbest hareketlilik her iki ülke vatandaşları için geçerli olmaya başlamıştır. Bu tarihler arasında 2008 yılında Rusya ile Gürcistan arasında meydana gelen Güney Osetya Savaşı ile Rusya sınır kapılarını Gürcistan'a kapatmıştır. Bu karar Türkiye'nin hem hedef hem de transit bir ülke olması olasılığını arttırmıştır. İki ülke arasındaki döngüsel emek hareketliliği iş gücü piyasalarındaki bilginin Gürcülerde toplanmasını sağlayarak göç sistemi oluşturmuş ve network sağlamıştır (Özbey, 2018: 149). $\mathrm{Bu}$ sonuç sadece Gürcüler açısından bir sonuç değildir aynı zamanda Türkiye'den çok sayıda sermaye grubu Gürcistan'ın önemli şehirlerinde yatırımcı konumundadır. Bu iki farklı durum Gürcülerin Türkiye'de alt, Türkiyelilerin Gürcistan'da daha üst sektörlerde iş yaptığını göstermektedir.

Sovyet Birliği döneminde bazı parça üretimleri Gürcistan'da yapılmaktaydı. Sovyet Birliği dağıldıktan sonra yapılan üretimler durduğu gibi parça üretiminin bütünü oluşturabilecek yeterliliğe sahip olmadı̆̆ından gerek sanayisi gerek tarım potansiyeli giderek ortadan kaybolmuştur (Wacquant, 2015: 19). 2003 Gül Devriminden sonra yüzünü hem ekonomik anlamda hem de kültür anlamında Batıya dönen Gürcistan, Rusya ile uzaklaşmış ve 2008'de meydana gelen Rusya-Güney Osetya savaşı ile birlikte Rusya ile olan ilişkiler kopma noktasına gelmiştir. Neoliberal politikalarının da etkisiyle bugün Gürcistan AB'ye 
üye olma yolunda ilerlemektedir (Baumann, 2012: 269-271). Bu politikalarla Gürcistan'ın ticaret hacmi artmış ve turizm potansiyeli yeniden inşa edilmiştir. Gürcistan'ın Batı dünyasına açılma politikası yüzde altı büyümesine sebep olsa da bu büyümenin etkisi tüm sınıflarda eşit düzeyde etkili olmamıştır. Bu büyümeyi sağlayan asıl şey turizm, piyasa hizmetleri ve inşaat sektörü olmuştur.

Sovyet Birliği'nin dağılması ile birlikte Gürcistan'ın iş gücü piyasalarında önemli değişiklikler yaşanmıştır. Sovyet dönemindeki sosyal ve ekonomik haklardan mahrum kalan insanlar bağımsızlıkla birlikte kamu dışında bir sektör olmadığından önemli oranda işten çıkarmalar meydana gelmiş ve işsizler ordusu yaratmıştır. 1990'da sanayide nüfusun \% 20'si çalışıyorken 2007 'de \% 5'e kadar düşmüştür. Bugün ise istihdamın önemli bir oranını hizmet sektörü yüklenmiş̧tir. Sovyet döneminde nüfusun \% 53'ü kendi yetiştirdiği sebze ve meyve ile geçinebiliyorken neoliberalizm ile birlikte serbest pazar anlayışı artık buna imkân vermemektedir. Bu haliyle Gürcistan ileri kapitalist merkez ülkelerinin çevre ülkesi konumundadır. Nüfusun önemli bir kısmı az topraklı olması sebebiyle tarımla uğraşmak geçim tipi tarım yapmak anlamına gelmektedir. $\mathrm{Bu}$ haliyle de çiftçiler pazar ile rekabet edememektedir. Yapısal eşitsizlikle birlikte ortaya çıkan yoksulluktan en fazla etkilenen kadınlar ve 65 yaş üstü nüfustur. Gürcistan'ın ortanca yaşın 39 olduğu göz önünde bulundurulduğunda önemli oranda yaşlı nüfusu barındırdığı için sosyal devlet harcamaları devlet bütçesinde önemli yer tutmaktadır. Bu ekonomik sistem ve onun yarattığı mağduriyet ile birlikte Gürcistan'ın aktif nüfusu uluslararası emek hareketliliğe katılmaktadır. Bu hareket ile birlikte Gürcistan nüfusunun nitelikli iş gücünü de kaybetmeye başlamıştır. Pazar ekonomisine ani bir şekilde geçen Gürcistan aynı ölçüde demokratik sisteme geçiş yaşamamıştır. Bu durum hem muhalefet yetersizliği hem de sivil toplumun yetersizliği ile ilişkilidir. Böyle olunca devlet ile parti iç içe geçmiş ve özgürlüklerin gelişiminde gecikmişlerdir. Parti devleti ile birlikte hukuk devleti de siyasallaşmış ve medya aynı tekel sisteme dahil edilmiştir. İç politikadaki bu durum hem de uluslararası hareketliliğin çekiciliği ile hem de 2000'lere kadar vizesiz seyahat hakkı olmasıyla önemli hareket noktası Rusya olmuştur. Rusya ile var olan tarihsel, kültürel ve ekonomik ilişkiler sebebiyle de Gürcistan'ın en yoksul kişilerinin de iş gücü hareketine katılmasına sebep olmuştur. Uluslararası harekete katılan nüfusun gönderdiği havalelerin ülke ekonomisine faydalı olacağını öngören Gürcistan 1990'ların ortalarından beri emek hareketliliğini desteklemektedir. 2000 yılında Rusya'nın vizesiz geçişi kaldırması ile Rusya'ya olan emek hareketliliğinin yoğunluğunu azaltmış (fakat yine ilk sırada) ve Batı Avrupa önemli hedef bölgesi haline gelmiştir.

Böylesi bir ekonomik ortamda 1991 yılında küresel ölçekte Sovyet sonrası ülkelerin emek hareketliliğinde bulunmasının yanında özellikle 2008'den sonra giderek artan oranda Türkiye'ye çay tarımı için gelen Gürcüler, harekete katılmadan önce bazı sebepler ortaya koymuşlardır. Araştırmaya katılanların kimi işinden ayrılmış, iflas etmiş, ekonomik durumu kötüleşmiş kimi ise evlilik için para biriktirmek istediği için hareket ettiklerini belirtmişlerdir. Türkiye ile var olan coğrafi yakınlık hareketin maliyetini düşürmüştür. Gürcistan'da iş̧̧i ücretleri geçinmek için yeterli olmadığından ve Türkiye ile Gürcistan arasındaki döviz farkının Gürcüler lehine olması hareketi cazip kılmaktadır. Her bir hareket başka bir hareketi doğurduğu için Gürcüler arasında göç kültürü oluşmuştur. Çay hasadı için emeği satmak iş gücü piyasası açısından oldukça esnek bir durum ortaya çıkarmaktadır. Nitekim hafta sonu bile Gürcistan'daki üniversite öğrencileri çay hasadı için döngüsel emek hareketliliğine katılmaktadır.

Gürcistan'da yaşanan gelişmeler ile çay bölgesinde yaşanan değişmeler birbirine paraleldir. Çay bölgesi ilk olarak emeğe ihtiyaç duyduğu 2000'li yıllarda bu emeği bölge içinden karşılamıştır. Bu karşılama durumu oldukça gelenekseldir fakat ücretli bir emek söz konusudur. Bu tarihten önce de daha çok imece usulü ile emek ihtiyacı karşılanmaktaydı. Emeğini ücretli emeğe dönüştüren bölge halkının önemli bir kısmı da az topraklı köylülerden oluşmaktaydı. Fakat burada bu emeğin (imeceücretli) hemen tamamı kadınlar tarafından karşılanmaktaydı. Çay tarımının en yoğun olduğu alanlar kıyı bölgeleridir ve bu bölgeler aynı zamanda il ve ilçe merkezlerine karşlık gelmektedir. Bu bölgeler demografik dönüşümü daha erken yaşadıklarından ücretli emeğe ihtiyacın ilk olarak ortaya çıktığı alanları da oluşturmaktadır. Bu sebeple hem bölge içi ücretli emek hem de Gürcü emeği ilk olarak buralarda kullanılmıştır. $\mathrm{Bu}$ arz sebebiyle Sovyet döneminde çay tarımı tecrübesi de bulunan nispeten hasat konusunda uzmanlaşmış Gürcü emeği bu işgücü açığını doldurmuştur. Özellikle 2008 ve sonrasında Gürcü emeği sadece çay hasadında değil ayrıca özel çay fabrikalarında çaya ilişkin tüm aşamalarda çalışmaya başlamışlardır. Zaman içerisinde Gürcülerin geliştirdiği sosyal sermayeler bu hareketin ulaşılabilirliğini arttırmıştır. İş gücü piyasalarında ağları genişletmek ve var olan konumu korumak adına Gürcüler her zaman aynı yere ve aynı işe döngüsel emek hareketliliği yapmaktadır (Zelinka, 2017: 43). Bu durum da bir yönüyle esnek işgücü havuzu için yedek işgücü sağlayarak yerli işçi sınıfını kısmen proleter olmaktan çıkarmaktadır (Wacquant, 2015: 41). 
Gürcü emeğinin yerli emeğin yerini almasının anlatıldığ yukarıdaki süreç aslında feminizasyon sürecinin etnikleşme sürecine görev teslim ettiğine işaret etmektedir. Feminizasyon kısmen ücretli fakat çoğunlukla aile emeği olarak ücretsiz olarak sürerken etnikleşme özellikle 2020 Covid-19 sürecine kadar ücretli bir emek biçimi olarak sürmekteydi.

\subsection{Gürcü Emeğinin Etnikleşmesi}

Etnikleşme süreçlerine ilişkin ilk kısımlarda elde ettiğimiz teorik bilgilerden hareketle Gürcü emeği de benzer süreçlerden geçer. Gürcülere yönelik ön plana çıkan söylemlerde bir tanesi onların hırsız olduğudur. $\mathrm{Bu}$ durumun gerçekte böyle olup olmaması önemli değildir. Hırsız olmak ile Gürcü olmak birleştirilir. Gürcülere ilişkin yerli halkın söylemlerinde etnosentrizm bulunmaktadır. Başka bir ifade ile Gürcülere yönelik gündelik hayatta edindikleri izlenimleri Gürcü olmak üzerinden değerlendirmektedirler. Çünkü onlara göre Gürcülerin nankördür ve ne yapılırsa yapılsın iyilikten anlamayacaklardir. Gürcülerin Hristiyan olması bu sebeple alkol ve domuz eti ile ilişkili olmaları sebebiyle de emek etnikleştirilmektedir. Alkol sebebiyle Gürcülerin kafalarının yarım çalıştığl ve birçoğunun geri zekâll olduğu da vurgulanır. Geri zekâlı olma tespiti de yerli insanların Gürcülerden üzerinden deneyimledikleri örnekler üzerinden çarpık bir şekilde üretilmektedir. Çarpık bir tarihsel bir arka planla Gürcülerin Türkleri sevmedikleri ve Türklere karşı kin ve nefretle hareket ettikleri de ifade edilmektedir. Böylece Türklerden kin ve nefret duyulduğu düşünülen Gürcülerin emeğinin sömürülmesine karşı1lk olarak herhangi bir tepkinin verilmesi zor gözükmektedir. Gürcüler kazandıkları paraları yarın yokmuşçasına harcadığına ilişkin de bazı algılar vardır. Bu algı ise yerli insanların Gürcistan'a gitmesi ile oradaki deneyimlerine ilişkin üretilmektedir. Hâlbuki Gürcistan'da gördüğü Gürcü üzerinden çay hasadına gelen Gürcü'yü değerlendirmektedir. $\mathrm{Bu}$ haliyle de oldukça fazla genelleştirme ile bir Gürcü'nün eylemi tüm Gürcülere mâl edilmektedir. Bu haliyle bu bakış oldukça ahlakçı ve özcüdür. Böylece kazandığı paranın kıymetini bilmeyen bir Gürcü'nün ahlaken sömürülmesi de kolaylaşır. Gürcistan'ın Türkiye'den farklı bir inanca mensup olması üzerinden de Gürcülere yönelik bu farkl1lıklar vurgulanarak da etnikleşme süreci desteklenir. Gürcülerin sürekli olarak cenabet oldukları, sünnetsiz oldukları bu sebeple çayın bereketinin kaçtığı, rızkın bittiği ifade edilir. Din farkl1lığ içerisinden üretilen bu olumsuz duruma karşılık olarak iş emek sürecine dahil olduğunda Gürcülerin gâvur gibi güçlü olduğu söylenerek zıtlık üretilir. Çayın emek sürecine katılmak için işçilerin beslenmelerine dikkat ederek enerji toplaması gerekmektedir. Fakat buna karşıllı olarak yerli insanlar Gürcülerin güvercin gibi sürekli ve çok yediklerinden şikâyet etmektedir. Bu durumda da yemekle yoğun emek arasındaki bağlantı koparılarak iş gücünün etnik vurgusu ön plana çıkmaktadır.

Etnikleşme süreci sadece yerel halk ve göçmen emeği arasında değil aynı zamanda göçmen emeğinin farklı etnik unsurlardan oluşması durumunda da gerçekleşir. Gürcistan'dan gelen emek sadece Gürcü Hristiyanlardan oluşmamaktadır. Bu grubun içerisinde Gürcistan Müslüman halklarından olan Azeriler de bulunmaktadır. Bir katılımcı "Azeriler geleceğine Gürcüler gelsin Türk'ü hiç sevmezler bakmayın tek millet iki devlet söylemlerine. Gürcü'yü yine kullanırız Azeri'yi öyle her yerde kullanamayız" (KM) (Öksüz, 2019: 167) bu durumu açıklar niteliktedir. Burada Azeri ile Gürcü’yü bu şekilde ayrıştırmasının ve bu ayrışmanın Azerilerin aleyhine olmasının sebebi paradoksaldır. Çünkü Azerilerin Müslüman olması, Türkçe konuşabilmeleri ve Türk olmaları sebebiyle ulusun hâkim unsuru ile oldukça benzerdir. Bu sebeple Azeri'ye karşı bu söylem aslında Gürcülere yöneliktir. Böylece Gürcü emeği etnikleşme sürecinde en alta itilerek sömürüye hazır hale getirilir. Buna rağmen Gürcülerin Türkiyelilere çok benzediği dişardan bakıldığında Gürcü mü, Türk mü anlaşılmadı̆̆g ifade edilir. Buradaki söylem de aslında Yahudilere yıldız takılması gibi hâkim unsurdan olabildiğince etnik emek ayrıştırılmak istenmektedir. Etnikleşme süreçlerini meşrulaştırma adına bazı ekonomik sorunlar Gürcülere atfedilir. Gürcülerin gelmesi ile birlikte çay fiyatının düştüğü buna karşılık Gücülerin yılda 70 milyon dolar ${ }^{1}$ kazandığ 1 iddia edilir. Çayın fiyatının düşmesinin Gürcülerle ilişkili olduğu durumu yoğun Gürcü emeği ile birlikte çayın kısa sürede toplanması ve özel sektörün bunu firsat bilerek yaş çay fiyatını düşürdüğüne göndermede bulunur. Hâlbuki bu süreci bu halde getiren yerli insanların etnik emek kullanma biçimleri ve özel söktürün firsatçıllğı ile ilişkilidir. Burada da asıl hedef sermaye olması gerekirken Gürcüler olmuştur. Gürcülerin 70 milyar dolar gibi uçuk bir rakam kazandıkları iddia edilerek ücretlerin düşürülmesine de gönderme de bulunmaktadır. Hâlbuki Türkiye iş insanlarının Gürcistan'daki turizm ve inşaat sektöründen elde ettikleri milyar dolarlar görmezden gelinmektedir.

Gürcülerin etkinleşme süreçleri inşa edilirken bazı durulmalarda olgu biyolojikleştirilir. Bitkiler ve tohumları hastalıklar gibi belli yollarla farklı mekânlara taşınırlar. Rüzgâr, hayvan, akarsu vb. durumlar bunda etkili olduğu gibi bazen insanlar tarafından da istenmeden de olsa taşınabilirler. Çay

1 https://bit.ly/39HJWy6 Erişim Tarihi: 21.04.2019. 
bölgesinde yabani ve arsız bir tür olan ve ismine "şeytan kuyruğu” denen bir bitki türemiştir. Bunun Gürcüler tarafından getirildiği ifade edilir. Ayrıca bitkilerin öz suyunu emen, fasulye gibi tarım ürünlerine zarar veren dıştan kemikli bir kelebek de türemiştir. Bu kelebeğe de "Gürcü Kelebeği" denmektedir. Her iki durumda Gürcü olma durumu ile bitki ve hayvanlara atfedilen özellikler birleştirilerek emeğin sermaye tarafından sömürülmesine ortam hazırlamaktadır. Bu ortama bazı milliyetçimuhafazakâr medya da zemin hazırlar. Medyada Gürcülere yönelik yer alan ifadelerde Gürcülerin zulmettiği, cinayet işledikleri, suçlu oldukları, onlara göz yumulduğu, Rize'yi işgal ettikleri vurgulanır². Türkiye'de Gürcü emeğinin bu şekilde etnikleşme sürecine doğru itilmesinin Gürcistan'da da karşılığ vardır. Çünkü bu şekilde dışlanan ve etnik kimlik üzerinden ötekileştirilen Hristiyan Gürcüler Türkiye'nin Müslüman olması üzerinden dişlama ve etnikleştirilme genelleştirilerek Türk ve Müslüman olmaya indirgenir. Gürcüler ülkelerine döndüklerinde oradaki Müslüman ve Türk nüfuslara mesafelenirler. Böylece Gürcistan'daki iş gücü piyasalarına ilişkin sermaye açısından istenen etnikleşme süreci de Gürcistan'da güçlenir.

Gürcülerin bu şekilde etnikleşmesi Türkiye'deki Kürt emeğinin etnikleşmesi ile de ilişkilidir. Çünkü Gürcü'ye alternatif olarak Kürtlerin önerilmesi karşısında alınan cevaplar durumu oldukça aydınlatır. Ayrıca Covid-19 sürecinde Gürcülerin gelememesi ile birlikte de yine Kürt emeğini çay bölgesi talep etmemiştir. Bölge halkı Gürcülerin gelmemesi durumunda Suriyelilerin, Azerilerin veya Tatarların gelebileceğini ifade etmişlerdir. $\mathrm{Bu}$ ifadeler aslına Gürcü emeğine alternatifleri ortaya koyduğu gibi Kürtlerin emeğinin düşünülmediğine de işaret etmektedir. Çünkü onlara göre Kürtler Apocudur, güvenilir değillerdir, kavgacıdır ve onları sevmemektedirler. Ayrıca yöre halkı on tane Gürcü'ye güvenir fakat bir tane Kürt'e güvenmeyeceğini söylemektedir. Kürt'e karşı da Gürcü'nün kapı komşusu olduğunu ve komşuluk hukuku gereği Gürcü’nün gelmesi gerektiğini savunur. Bu söylemlere bakılırsa yukarıda Gürcüleri etnikleştirme adına söylenen şeyler burada tam tersi bir durum alır. Burada Kürtlerin Müslüman ve sünnetli olmasının önemi yoktur. Nasıl ki Türkiye'deki süreçler Gürcistan'daki belli grupları iş gücü piyasaları açısından etnikleştiriyorsa çay bölgesindeki Kürt'e olan bakış da Türkiye'deki Kürtlerin iş gücü piyasaları açısından etnikleşmesine hizmet etmektedir. Kürtlere yönelik başka bir görüş de müstakbel Kürtlerin gelmesi ile birlikte rekabetin oluşacağı ve bu rekabet karşısında Gürcüler daha düşük ücretle çalışabileceklerdir. Bu da etnik gruplar arsında farklı kategoriler oluşturularak her zaman sermayeden taraf olunmasını sağlar.

Gürcülerin söylemler üzerinden bu şekilde etnikleşmesinin bazen de STK ve kamu kuruluşları bir araya gelerek etnikleșmeyi kurumsallaştırmak istemektedirler. Bunun için de Gürcülerin ne kadar ücret alacakları, kaç saat çalışacakları, hangi yemek öğünleri verilip verilmeyeceği tartışılır . Bu tartışma yapılırken de temsil olarak bu toplantılarda hiçbir Gürcü bulunmaz. Kimileri ise Gürcü emeğini ücret düzeyinde sözde nitelik üzerinden bölmeye çalışır. Onlara göre de Gürcülerin topladıkları çayın niteliğine göre farklı ücret tarifeleri uygulanmalıdır. Bir bakıma Gürcülerin toptan etnikleștirilmelerinin yanında Gürcü emeği alt gruplara ayrılarak yeniden düzenlenmek istenmektedir. Buna gerekçe olarak da fındıkta Gürcülerin 50-55 TL'ye çalıştığı örnek gösterilmektedir. $\mathrm{Bu}$ karşılaştırma da findık ve çay iş̧̧iliği arasındaki emeğin yoğunluğu görmezden gelinmektedir. Bu konuda ÇAYSİAD ${ }^{4}$ önemli bir atılım yapar ve çaydaki emeğin bölgeden karşılanması gerektiğini gerçeklikten uzak bir şekilde savunur. Gerçeklikten uzaktır çünkü bölgedeki emeğin yerini Gürcüler almış değildir, bölgenin emek gücü çay piyasasından belli sebeplerle (demografik dönüşüm, neoliberal politikalar) çekildiği için Gürcü emeğine ihtiyaç duyulmuştur. ÇAYSİAD genel sekreteri bir yazısında ${ }^{5}$ emek sorununu ele alır. Sekreter çözüm olarak çay bahçelerinin birleştirilmesini savunur. Bunun için de çay tarımına iliş̧in mülkiyeti üçe ayırır; ilk grupta çay bahçesine sahip olup hane halkı toplam geliri içerinde çay gelirinin bir önemi olmayanlar yer alır. İkinci grupta çay hasadını ücretli emekle yapanlar yer alır. Ki bu grup sorunun temel kaynağı olarak görülür. Üçüncü grupta ise çaydan elde ettiği gelirin hane halkı için temel olduğu ve bu sebeple de kendi emeği ile çayı hasat edenler yer alır. Çay tarım alanlarının birleştirilmesinden kasıt yukarda yer alan ilk iki grubun bahçelerinin șirketler ölçeğinde çay alanlarının yönetilmesidir. Bir bakıma az topraklı köylünün yarıcılık yaptığı alanlar şirketlere devredilecektir ve bu şirketler de plantasyonlarda olduğu haliyle işleyecektir. Böylece söylemsel ve politik olarak inşa edilen etnikleșme sürecine daha vahşi bir kapı aralanmak istenmektedir.

Türkiyeli aracılar Gürcülerden konaklama ücreti olarak her gün kişi başı 10 TL kesinti yapmaktadır. Bunun yanında aracılar Gürcülere iş buldukları zamanlarda günlük yevmiyelerinden 10 TL daha kesinti yapmaktadır. Bazı aracılar bu parayı almak yerine karşıllı̆ında bir günlük emeğine el koymayı tercih

\footnotetext{
https://bit.ly/3atXAUK Erişim Tarihi: 21.04.2019.

https://bit.ly/3rj1t5t Erişim Tarihi: 21.04.2020.

https://bit.ly/3rmTQee Erişim Tarihi: 04.04.2020.

https://bit.ly/3oTjQg1 Erişim Tarihi: 21.04.2020.
} 
etmektedir. Bu durum göçmenlerin pasaportunu gasp etmek gibi bedenini gasp etmeye benzemektedir. Günlük kesintiler yerine bir tam gün emeğine el koymak daha acımasızdır. Gürcüler bazen kilo işi kimi zaman da günlük yevmiye biçiminde çalışmaktadır. Günlük yevmiye 130-150 TL iken şayet bir kişi $500 \mathrm{~kg}$ çay topladığında aldığı ücret $250 \mathrm{TL}$ olmaktadır. Fakat aracı her iki ücretten de 10 TL kesmektedir. Oysaki on liranın günlük yevmiye ve kilo işi toplama içindeki oranı farklıdır. Tüm bu kesintilerden kabaca bir hesap yapılabilir. Bir aracı tüm koşullar sabitse bir Gürcü'den günlük kırk lira kesinti yapmaktadır. Şayet aracının yüz kişi ile çalıştı̆̆ ve bir çay hasadı döneminin yirmi gün sürdüğü düşünülürse ayrıca çayın yılda üç kez toplandığı hesaba katılırsa bir aracının yıllık kazancı 240.000 TL'yi bulmaktadır. Gürcülerden günlük para kesintileri yapmak yerine bedenine bir günlük el koyan aracıların kâr sistemi daha farklıdır. $\mathrm{Bu}$ aracılar az topraklı köylüdür ve kendi çayını Gürcülere ücretsiz toplatmaktadır. Ayrıca bu aracılar 30 ton yarılık çay alarak tüm bu çayı Gürcülere ücretsiz toplatmaktadır. Böylece bu aracı az topraklı toprak ăgast/yarıcı toprak ăgası (plantasyonlarda olduğu gibi) konumuna yükselir (Öksüz, 2019: 155). Bu aracı aynı zamanda özel çay fabrikasının eksperidir. $\mathrm{Bu}$ alım yerinde kendi çayını sattığı gibi diğer çay üreticilere daha düşük ücretle peşin para vererek üreticilerin çayını vadeli ve yüksek ücrete çay fabrikasına yeniden satar. Burada üzerinde durulması gereken mesele emeğin feminizasyon ile etnikleşme sürecinin bu kadar benzer olmasının arka planda toplumsallığın üretim biçiminin de aynı olması meselesidir. Bu sebeple de feminizasyon ve ırk ilişkisine işaret etme adına kadın ırkı kavramsallaştırılması kullanılır.

\section{TARTIŞMA VE SONUÇ}

$\mathrm{Bu}$ çalışmada çay hasadının ihtiyaç duyduğu emeğin feminizasyon süreci ile etnikleşme süreci birbiriyle ilişkili fakat ayrı birşekilde ele alınmıştır. Bu açıdan emeğin feminizasyonunun arka planında yatan tarihsel ve ekonomik boyut ile emeğin etnikleşmesi arkasında yatan tarihsel ve ekonomik boyut birbirine paralellik göstermektedir. Tarımda ücretsiz çalışan kadınların emeği ev işi olarak görülmüş̧ür. Bu açıdan da kadının emeği hem ucuz emek hem de ücretsiz aile işçisi olarak kodlanmıştır (Candan ve Günal, 2013: 11). Emeğin feminizasyonu sermaye ve emek arasında bir çatışma alanı yaratır ve cinsiyet de bu çatışma alanının içinde önem kazanır. Kapitalizm ona harcanan emeği niteliksizleştirir ve niteliksizleştirmeyi yeniden üretir. Çay hasadındaki kadın emeği hem görünmezliği açısından hem de toplumsal değeri açısından niteliksizleştirilmeye çalışılan bir emektir. Çünkü buradaki feminizasyon kapitalist ataerkil sistemin erkeğe açtığı alanın zıddı olarak karışımızda bulunmaktadır. Bu sistem erkeklerin değişim değeri için üretmesi, kadınların kullanım değeri üretmesinin üstünü örtmüş ve erkek iktidarı için bir temel oluşturmuştur (Donovan, 1997: 134). Böylesi bir toplumsal üretim süreci aynı zamanda bir yeniden üretim sürecidir ve üretim koşulları yeniden üretimin koşullarıdır (Erdoğan, 2019: 34). Nitekim devletin ideolojik aygıtları içerisinde olan ailenin yeniden üretim noktasında önemli olduğunu bilgisi (Althusser, 2014) bize bu yeniden üretim konusunda kadının konumunu verir. $\mathrm{Bu}$ açıdan da emeğin kadın üzerinden ücretsiz üretilmesi ideolojiktir. İdeolojinin her yerdeki varlığı bu anlamda rızanın üretimine de sebep olur (Herman ve Chomsky, 2012). Aile içinde ücretsiz kadın emeğinin üretiminin ücretli kadın emeğinin üretimine dönüştüğü anda da benzer sömürü ilişkileri devam eder. Eril tahakküm nasıl kadın emeğini aile içerisinde hegemonya altına alıyorsa eril sermaye sistemi de ücretli emekte aynı işlevi görür. Ki burada ÇAYKUR'un varlığı hem bölgeyi ideolojik olarak dönüştürmede hem de ücretli emekte yoğun olarak erkek emeğinin kullanılmasını dayatması, durumu yeniden üreterek kadın emeğini konumlandırmış̧ır. Burada feminizasyon sürecini üreten salt erkekler değildir aynı zaman da kadınlar da bu sürecin yeniden üretim yolu ile feminizasyona katkıda bulunurlar. Çünkü kadınların kız çocuklarına kıyasla erkek çocuklara önem vererek sistemin sürdürülmesini sağlarlar. Buradaki yanılg1 ailenin toplam olarak ürettiği emeğin ailenin ortak çıkarları için kullanıldığı yanılsamasıdır. Çünkü ortak çıkar denilen şey kadın emeği üzerinden bir ortak çıkar değildir. Ortak emek ataerkilliğin ortak çıkarına hizmet edecek şekilde organize edilmektedir. Bu durum da sosyal-ekonomik politikaların bireyi değil haneyi baz alarak (Aile Bakanlığı gibi) üretilmesi sonucunu doğurmaktadır (Dedeoğlu, 2000: 145). Bu süreç aslında aile içi gelir dağılımının eşitsizliğini ortaya çıkarmaktadır. Nitekim erkeğin edindiği gelir aileye gelmeden önceye kadar kendi özel ihtiyaçları karşılamaya imkân vermesine rağmen kadının böyle bir firsatı yoktur. Bu haliyle de çalıştığı halde ihtiyaçları ancak erkeğin kontrolü ve denetiminde giderilmektedir. Bu açıdan çay hasadında emeğini ücretli bir şekilde satan kadınların temel motivasyonu özel ihtiyaçlarını gidermek bazen de kız çocuklarını bu emeğe dâhil ederek onlara çeyiz hazırlanmak istenmektedir. Bu durum gösteriyor ki kadın kendi özel ihtiyaçlarını karşılamak için ayrıca emeğini satmak zorundadır. Çay hasadında emeğin etnikleşmesi ile birlikte kadın emeğinin ücretli emeğe dönüşmesi kısmen hizmet sektörü yolu ile olsa da aslında birçoğu ev içi emekte ve diğer tarım ürünlerinin yetiştirilmesinde kullanılmaktadır. Çay bölgesindeki kadının ücretli emeğe katılmamasında toplumsal cinsiyet rejimi ve hane halkının toplam geliri içerisinde kadın emeğinin ücretli işe yönlendirilmesi için gerekli olmadığı kabul edilse bile kadının var olan sosyal ve 
kültürel sermayesi onu vasıflı bir işte istihdam edilmesine engel olmaktadır. Kadın emeğinin vasfının düşük olması da benzer şekilde ideolojik bir toplumsal cinsiyet temelinden kaynaklanmaktadır. Bu süreci çay bölgesinde yasal olan miras hukukunun hala işlememesi de desteklemektedir.

Çay hasadında kullanılan emeğin Gürcüler üzerinden etnikleşme süreçleri de benzerdir. Çünkü kadın emeği üzerinden işleyen süreç bu sefer etnikleşme süreci üzerinden işlemektedir. Kadına uygulanan tahakküm ve biyolojisine atfedilen değersizliğin benzeri de Gürcülere uygulanmaktadır. Her iki durumda da artı değere el koyma gerçekleşmekte fakat aktörler değişmektedir. Gürcü emeğinin artı değerine el koyan aktörler devlet, fabrika patronları, çay bahçesi sahipleri, esnaf ve aracılardan oluşmaktadır. İlk bölümlerde etnikleşme sürecinde ulus devletin rolüne vurgu yapılmıştı fakat burada Gürcülerin sınır kapısından girip çay bahçesine varıncaya kadar Gürcülerle bulunduğu ilişkilerde artı değere el koyar. Gürcülerin fabrikalarda ortalama ücretin altında güvencesiz çalışmaları ile de artı değerine el konulur. Çay bahçesi sahipleri de özellikle yevmiye usulü çalışanlar açısından daha uzun sürelerde çalıştırılarak artı değere el konulur. Kilo işi çalışan Gürcülere de gerçekte topladıklarından daha az kilo söylenerek emeğine el konulur. Esnaf ise hem çay için gerekli olan makas gibi malzemeler üzerinden hem de diğer ürünlerin fiyatını abartarak emeğe el koyar.

Son olarak Covid-19 virüsünün çaydaki emeğin feminizasyon ve etnikleşme sürecine etkisi üzerinde durmak gerekmektedir. Türkiye'nin pandemi sürecine dahil olduğu dönemlerde henüz çaya ilişkin bir gündem oluşmuş değildir. Fakat bu süreçte bölge halkı, fabrika patronları ve aracılar kendi bağlamlarında kaygılar yaşamaktaydı. Gürcistan sınır kapısının kapanması ile birlikte Gürcü emeğin bu yıl gelmeyeceği ihtimali ortaya çıktı. Buna ilişkin olarak da STK ve valilik düzeyinde emek gücünün bölgeden karşılanacağı ilan edildi. Hatta Fındıklı Belediyesi imece usulünü canlandırma adına bir proje başlattı. İŞKUR ile birlikte geliştirilen projeye göre asgari ücreti kurum karşılayacak ve gündelik olarak alınan yevmiyenin yanında İŞKUR ödemesi ile aylık altı bin TL gelir elde edilebilecektir. Bunun yanında Türkiye'de bazı illerde düzenlenen giriş çıkış yasakları sebebiyle büyük şehirlerden çay hasadı için memleketlerine gidemeyenlere özel izinler düzenlendi. Bu konunun başka bir bağlamı da virüs öncesi STK'ların Gürcü'ye alternatif olarak ürettikleri projelerin uygulanma zamanının üretimine yol açmıştır. Öte taraftan Covid sürecinde Gürcistan başarılı bir süreç yürüttüğünü ilan etmesiyle birlikte Gürcü işçiler de sınır kapılarının açılmasını talep etmiş̧ir. Nitekim yine bu süreçte İngiltere Romanya'dan ve Almanya farklı ülkelerden tarım emeğini koruma tedbirleriyle uçaklarla işçileri ülkelerine taşımışlardır. Gürcistan AB'ye doksan gün seyahat etme hakkını 2011 yılında elde etmiştir. 2021 yılı için Almanya Gürcistan'dan 90 gün çalışmak üzere günlük 9,5 Euro ücretle tarım işçisi talep etmiştir ${ }^{6}$. Bu ilana başvuran Gürcü vatandaş sayısı 97 bin kişiyi aşarak tüm Gürcistan nüfusunun yüzde 1,5'ine karşıllı gelmektedir? $\mathrm{Bu}$ deneyimler göstermektedir ki Türkiye'nin uluslararası emek hareketliliği politikasına ihtiyacı vardır. Çay bölgesinde fabrikalar, aracılar ve çay üreticileri Gürcü emeğinin gelmesinden yanayken otoriteler bundan yana değildir. Bu tarafll1ık durumu virüs öncesi de söz konusuydu. Bir alternatif olarak bu süreçte müstakbel doğudan çay fabrikalarında ve alım yerlerinde çalıştırılmak üzere Kürtler getirildi. Fakat çay toplama uzmanlaşma gerektiren bir iş olduğu için Kürt emeğinin çay toplama işinde kullanılması şimdilik mümkün değildir. Covid sürecinde çay emeği bölge iş gücü piyasalarından karşılanacağı politikası güdüldüğünden bu sefer yeniden emek ücretsiz feminizasyon sürecine girmiştir.

2020 yılı çay hasadı Karadeniz Teknik Üniversitesi'nde okuyan Senegalli öğrenciler, az sayıda Afganlar ve Türkiye'de oturma izni olan Gürcüler dışında yabancı emek olmadan gerçekleşmiştir. Bunun dışında Kars, Ağrı ve Erzurum gibi illerden çay toplama olmasa da alım yerleri ve fabrikalarda çalıştırılmak üzere işçiler getirmişlerdir. Bunun haricindeki emek ihtiyacı yerel halk tarafından karşılanmıştır. Bunu mümkün kılan Covid 19 bağlamında bazı sebepler vardır. Covid ile birlikte büyük şehirlerde yaşayan emekli nüfus çay hasadı için memleketlerine geri dönüşlerdir. Ayrıca eğitimin uzaktan olması sebebiyle yerel halk içerisindeki memur kesimin emeği aile içinde yeniden kullanılmaya başlamıştır. Çay toplama zamanı değişerek çay üreticileri gece ikide madenci lambaları ile çay toplamaya başlamışlardır. Covid 19 sebebiyle esnafin iş yapamaması ve buralarda çalş̧an kişilerin işten çıkmak durumunda kalması ile buradaki emek de çay hasadında kullanılabilmiştir. Bu emek türü de ücretli emek şeklinde değil aile içi ücretsiz emek şeklinde gerçekleşmiştir. Ücretli etnikleşme ve ücretsiz feminizasyonun bu şekilde birbirinin yerine kolayca devşiriliyor olması da ikisinin arkasında yatan sürecin sermaye ve kapitalist üretim açısından oldukça işlevsel olmasından kaynaklanmaktadır. Nasıl ki çay hasadı öncesi erkeklerin göç etmesi ile birlikte kadın emeği daha zor şartlarda genişleyerek aktive edildiyse, çay ile birlikte feminizasyon konumunu

6 https://bit.ly/2PsS9if Erişim Tarihi: 02.04.2021.

7 https://bit.ly/3cJ3nYH Erişim Tarihi: 02.04.2021. 
sürdürdüyse şimdi de Covid krizi ile birlikte Gürcü emeğinin etnikleşmesine karşıllk ücretsiz feminizasyon yeniden aktive edilmiştir. Buradan çıkan başka bir sonuç ise emek teorisi ortaya konulurken hem etnikleşme hem de feminizasyon süreçlerinin dikkatte alınmasıdır. Başka bir değişle emeğin feminizasyonu ve emeğin etkinleştirilmesi teorisi üzerinde kapsayıcı ve kapsamlı bir şekilde yeniden düşünülmelidir. Çünkü emek teorisi etnikleşme hele ki feminizasyon sürecini açıklamada yetersiz kaldığı gibi ayrı ayrı etkinleşme ve feminizasyon da emek teorisinden zaman zaman uzaklaşmaktadır. Bir sistem olarak kapitalizm ırkçılı̆̆ı meydana getiriyorsa cinsiyetçiliği de meydana getirir. İş gücünün etnikleşmesi emek gücünün tüm kesimleri için çok düşük ücretlere zemin sağlamak için vardır. Cinsiyetçilik sadece farklı hatta daha az beğenilmiş iş rollerinin kadınlara yüklenmesi değil, ırkçıllktan hiç de aşağı kalmayan bir yabancı düşmanlığıdır. Irkçılık insanları çalışma sisteminden dışarı atmayı değil onları içeride tutmayı hedefliyor; cinsiyetçiliğin de istediği budur (Balibar ve Wallerstein, 2017: 48).

\footnotetext{
Bilgilendirilmiş Onam: Katılımcılardan bilgilendirilmiş onam alınmıştır.

Hakem Değerlendirmesi: Dış bağımsız.

Yazar Katkıları: Çalışma Konsepti/Tasarım- M.Ö., E.M.Ö.; Veri Toplama- M.Ö., E.M.Ö.; Veri Analizi/Yorumlama- M.Ö., E.M.Ö.; Yazı Taslağı- M.Ö., E.M.Ö.; İçeriğin Eleştirel İncelemesi- M.Ö., E.M.Ö.; Son Onay ve Sorumluluk- M.Ö., E.M.Ö.

Çıkar Çatışması: Yazarlar çıkar çatışması bildirmemiştir.

Finansal Destek: Yazarlar bu çalışma için finansal destek almadığını beyan etmiştir.

Informed Consent: Written consent was obtained from the participants.

Peer-review: Externally peer-reviewed.

Author Contributions: Conception/Design of Study- M.Ö., E.M.Ö.; Data AcquisitionM.Ö., E.M.Ö.; Data Analysis/Interpretation- M.Ö., E.M.Ö.; Drafting Manuscript- M.Ö., E.M.Ö.; Critical Revision of Manuscript- M.Ö., E.M.Ö.; Final Approval and Accountability- M.Ö., E.M.Ö.

Conflict of Interest: The authors have no conflict of interest to declare.

Grant Support: The authors declared that this study has received no financial support.
}

\section{KAYNAKÇA/REFERENCES}

Akgiş, Ö. ve Karadaş, E. (2018). Bir sosyal ağ olan hemşehri derneklerinin yoksullukla mücadeledeki rolü üzerine uygulamalı bir araştırma: Bilecik Sinoplular Yardımlaşma ve Dayanışma Derneği. Ege Coğrafya Dergisi, 27(1), 21-34.

Althusser, L. (2014). İdeoloji ve devletin ideolojik aygitları. İstanbul: İthaki

Assaad, R. (2004). Why did economic liberalization lead to feminization of the labor force in Morocco and de-feminization in Egypt? Mediterranean Development Forum.

Aydın, O., Bostan, P. A. ve Özgür, E. M. (2018). Mekânsal Veri Analizi Teknikleriyle Türkiye'de Toplam Doğurganlık Hızının Dağılımı ve Modellenmesi. Journal of Geography, 37.

Badurashvili, I. (2012). Circular migration in Georgia. CARIM-East Explanatory Note, 12, 65.
Baldoz, R. (2004). Valorizing racial boundaries: Hegemony and conflict in the racialization of Filipino migrant labour in the United States. Ethnic and racial studies, 27(6), 969-986.

Balibar, E., \& Wallerstein, I. (2017). Irk ulus sını: Belirsiz kimlikler. İstanbul: Metis.

Baumann, E. (2012). Post-Soviet Georgia: It'sa long, long way to 'modern'social protection. Economies et Sociétés, 46(2), 259-285.

Bay, A. (2017) Rusya’ya Osmanlı içi Göçü (1830-1921). OTAM, 41.

Biryol, U. (2017). Gurbet pastası: Hemşinliler, göç ve pastacılık. İstanbul: İletişim Yayınları

Block, S., Galabuzi, G. E., \& Weiss, A. (2014). The colour coded labour market by the numbers. Toronto, ON: Wellesley Institute

Bonacich, E., Alimahomed, S., \& Wilson, J. B. (2008). The racialization of global labor. American Behavioral Scientist, 52(3), 342-355.

Bonnett, A. (1998). How the British working class became white: The symbolic (re) formation of racialized capitalism. Journal of Historical Sociology, 11(3), 316-340.

Candan, E., \& Günal, S. Ö. (2013). Tarımda Kadın Emeği. Turkish Journal of Agricultural Economics, 19(1).

Caraway, T. L. (2005). The political economy of feminization: From "cheap labor" to gendered discourses of work. Politics \& Gender, 1(3), 399-429.

Carter, B., Green, M., \& Halpern, R. (1996). Immigration policy and the racialization of migrant labour: The construction of national identities in the USA and Britain. Ethnic and Racial Studies, 19(1), 135-157.

Cranford, C., Vosko, L., \& Zukewich, N. (2003). The gender of precarious employment in Canada. Relations industrielles/ Industrial relations, 58(3), 454-482.

Çağatay, N., \& Özler, Ş. (1995). Feminization of the labor force: The effects of long-term development and structural adjustment. World development, 23(11), 1883-1894.

Çakmak, H., \& Yaman, I. (2018). Post-Sovyet Dönemde Türkiye'ye Yönelen Kadın Emek Göçü Profili: Kumkapı'da Tekstil Sektöründeki Satış Temsilcisi Kadınlar Örneği. Middle East Journal of Refugee Studies, 3(2), 197-228.

Çınar, S., \& Lordoğlu, K. (2015). Mevsimlik Tarım İşçiliğinde Tekil Bir Analiz: Karasu Fındık Toplama İşçileri. Mesleki Sağlık ve Güvenlik Dergisi (MSG), 10(38).

Danovan, J. (1997). Feminist teori. İstanbul: İletişim Yayınları.

De Brauw, A., Li, Q., Liu, C., Rozelle, S., \& Zhang, L. (2008). Feminization of agriculture in China? Myths surrounding women's participation in farming. The China Quarterly, 194, 327-348.

Dedeoglu, S. (2007). Women workers in Turkey: Global industrial production in Istanbul. Bloomsbury Publishing.

Dedeoglu, S. (2014). Migrants, work and social integration: Women's labour in the Turkish ethnic economy. Springer.

Dedeoğlu, S. (2000). Toplumsal cinsiyet rolleri açısından Türkiye'de aile ve kadın emeği. Toplum ve Bilim, 86(3), 139-170.

Dedeoğlu, S. (2009). Eşitlik mi ayrımcılık mı? Türkiye'de sosyal devlet, cinsiyet eşitliği politikaları ve kadın istihdamı. Çalışma ve Toplum, 2(21), 41-54. 
Dedeoğlu, S. (2010). Endüstriyel Üretimde Kadın ve Göçmen Emeği: Ataerkillik ve Enformel Emek. Kapitalizm Ataerkillik ve Kadın Emeği Türkiye Örneği, 249-276.

Dedeoğlu, S., \& Gökmen, Ç. E. (2020). Göç Teorileri, Göçmen Emeği ve Entegrasyon: Kadınların Yeri. Türkiye'de Göç Araştırmaları, 18.

Dedeoğlu, S., \& Öztürk, M. Y. (2010). Kapitalizm, ataerkillik ve kadın emeği Türkiye örneği. İstanbul: Sav Yayıncılık.

Deere, C. D. (2005). The feminization of agriculture? Economic restructuring in rural Latin America (No. 1). UNRISD Occasional Paper.

Deniz, A. (2018). Türkiye'ye Filipinli dadı göçü: aracı firmaların rolünü anlamak. Coğrafi Bilimler Dergisi, 16(2), 289-301.

Deniz, A., \& Özgür, E. M. (2010). Rusya'dan Türkiye’ye Ulusaşiri Göç: Antalya'daki Rus Göçmenler. Ege Coğrafya Dergisi, 19(1), 13-30.

Deniz, A., \& Özgür, E. M. (2013). Antalya'daki Rus Gelinler: Göçten Evliliğe, Evlilikten Göçe. İstanbul Üniversitesi Sosyoloji Dergisi, 3(27), 151-175.

Deniz, A., \& Özgür, E. M. (2015). Rus kadınların emek göçü: Antalya örneği. Lülüfer Körükmez \& İlkay Südaş (Der.) Göçler Ülkesi içinde, 115-133.

Deniz, A., \& Özgür, E. M. (2020). Mixed marriage and transnational marriage migration in the grip of political economy: RussianTurkish Case. Turkish Studies, 1-25.

Donovan, J. (1997). Feminist Teori. İstanbul: İletişim Yayınları.

Enriquez, C. G. (2013). Circularity in a restrictive framework: Mobility between Morocco and Spain. Circular migration between Europe and its neighbourhood: Choice or necessity. Oxford: Oxford University Press. (pp. 114-140).

Erdoğan, S. (2019). Esnek Üretim Sistemi ve Emeğin Feminizasyonu: Mersin Konfeksiyon İşçileri Örneği. Mersin Üniversitesi, Yayınlanmamış Doktora Tezi.

Ergüder, B. (2006). Türkiye'de Kadın Emeğinin Değişen Yapısı: Enformel Kesimde Kadın Emeği ve Kadın Emeğine Talep. İstanbul Üniversitesi, Yayınlanmamış Yüksek Lisans Tezi.

Faist, T. (1995). Ethnicizatlon and racialization of welfare-state politics in Germany and the USA. Ethnic and Racial Studies, 18(2), 219-250.

Filali Adib, F. Z., Driouchi, A., \& Achehboune, A. (2013). Education attainment, further female participation and feminization of labor markets in Arab countries. Munich Personal RePEc Archive.

Gabriel, J. (1994). Racism, culture, markets. Routledge.

Gaddis, I., \& Klasen, S. (2011). Economic Development, Structural Change and Women's Labor Force Participation: A Reexamination of the Feminization U Hypothesis. Courant Research Centre: Poverty, Equity and Growth-Discussion Papers.

Galabuzi, G. E. (2005). The racialization of poverty in Canada: Implications for Section 15 charter protection. In The Twentieth Anniversary Year of Section 15 of the Canadian Charter of Rights and Freedoms. The National Anti-Racism Council of Canada National Conference, Ottawa-Thursday November 10 to Sunday November 13.

Geçgin, E. (2017). Ankara-Polatlı Örneğinde Sosyal Dışlanma Açısından Mevsimlik Tarım İşçiliği. Ankara Üniversitesi Sosyal Bilimler Dergisi, 1(1).
Gutierrez-Rodriguez, E. (2014). Domestic work-affective labor: On feminization and the coloniality of labor. In Women's Studies International Forum (Vol. 46, pp. 45-53). Pergamon.

Hann, C. M. ve Bellér-Hann, I. (2012). İki buçuk yaprak çay: Doğu Karadeniz'de; devlet, piyasa, kimlik. İstanbul: İletişim

Hardt, M. ve Negri, A. (2011). Ortak Zenginlik. İstanbul: Ayrıntı Yayınları. Hardt, M. ve Negri, A. (2020). Çokluk. İstanbul: Ayrıntı.

Herman, E. S. ve Chomsky, N. (2012). Rizanın imalatı: Kitle medyasının ekonomi politiği. Ankara: Bgst Yayınları.

Hossain, M. I., Mathbor, G. M., \& Semenza, R. (2013). Feminization and labor vulnerability in global manufacturing industries: Does gendered discourse matter?. Asian Social Work and Policy Review, 7(3), 197-212.

Hossain, M. I., Mathbor, G. M., \& Semenza, R. (2013). Feminization and labor vulnerability in global manufacturing industries: Does gendered discourse matter?. Asian Social Work and Policy Review, 7(3), 197-212.

Islam, S. (2016). Feminization of Employment and Gender Inequality of Bangladesh Labor Market: The Case of Garment Industries. Developing Country Studies, 6(2), 157-168.

İçduygu, A. (2004) Türkiye'de Kaçak Göç. İstanbul: İTO Yayınları

İlkkaracan, İ. (2013). Gender and Society in Turkey: The Impact of Neoliberal Policies. Political Islam and EU Accession.

İnal, R. (2018). Milliyetçiliğin Üretim İlişkileriyle İnşası: Çay Tarım Sanayi Devlet ve Toplum. Ankara Üniversitesi, Yayınlanmamış Doktora Tezi.

Jackson, P. (1992). The racialization of labour in post-war Bradford. Journal of Historical Geography. 18(2), 190-209.

Karaman, K., \& YILMAZ, A. S. (2011). Mevsimlik Tarım İşçileri ve Enformel İlişkiler Ağı: Giresun'da Çalışan Mevsimlik Tarım İşçileri Üzerine Bir Araştırma. Zeitschrift für die Welt der Türken/Journal of World of Turks, 3(1), 211-226.

Kaşka, S. (2006). Yeni Uluslararası Göç Hareketleri ve Türkiye'deki Moldovalı Kadın Hizmetçileri. Cultural Changes in the Turkic World. Würzburg, 71-89.

Kaya, A. (2009). Islam, migration and integration: The age of securitization. Springer.

Keyder, Ç. (1989). Türkiye'de devlet ve sinıflar. İstanbul: İletişim Yayınları.

King, R. (2012). Theories and typologies of migration: An overview and a primer. Willy Brandt Series of Working Papers in International Migration and Ethnic Relations 3/12. Malmö Institute for Studies of Migration, Diversity and Welfare (MIM) Malmö University.

Knight, M. (2016). Race-ing, classing and gendering racialized women's participation in entrepreneurship. Gender, Work \& Organization, 23(3), 310-327.

Köse, A. (2008). Küreselleşme Çağında Bir Aidiyet Zemini ve Örgütlenme Şekli Olarak Hemşehrilik. Akademik Incelemeler Dergisi, 3(1), 221-232.

Krahn, D. (2014). Immigration Policy and the Live-in Caregiver Program: The Racialization of Feminized Work in Canada's Labour Market, an Intersectional Approach. MANITOBA, 48. 
Kulaçoğlu, H. (2016). Dönmeye Direnmek. Karardı Karadeniz. İstanbul: İletişim Yayınları

Kurt, A. (2014). Küreselleşme kapsamında göç ve emeğin feminizasyonu (kadinsılaşması): trabzon hizmet sektöründe yabancı göçmen kadın emeği. Atatürk Üniversitesi, Yayınlanmamış Doktora Tezi.

Kurtoğlu, A. (2005). Mekânsal bir olgu olarak hemşehrilik ve bir hemşehrilik mekânı olarak dernekler. European Journal of Turkish Studies. Social Sciences on Contemporary Turkey, (2).

Kwok, S. M., \& Wallis, M. A. (Eds.). (2008). Daily struggles: The deepening racialization and feminization of poverty in Canada. Canadian Scholars' Press.

Lastarria-Cornhiel, S. (2006). Feminization of agriculture: Trends and driving forces. Rimisp.

Lechman, E., \& Kaur, H. (2015). Economic growth and female labor force participation-verifying the U-feminization hypothesis. New evidence for 162 countries over the period 1990-2012. New evidence for , 162, 1990-2012.

Lunn, K. (2000). A racialized hierarchy of Labour? Race, immigration and the British Labour movement, 1880-1950. In Racializing Class, Classifying Race (pp. 104-121). Palgrave Macmillan, London.

Luxton, M. (2014). Marxist feminism and anticapitalism: Reclaiming our history, reanimating our politics. Studies in Political Economy, 94(1), 137-160.

Mahmud, S. (2003). Is Bangladesh Experiencing a" Feminization" of the Labor Force?. The Bangladesh Development Studies, 1-37.

Mahmud, S. (2003). Is Bangladesh Experiencing a" Feminization" of the Labor Force?. The Bangladesh development studies, 1-37.

Maldonado, M. M. (2009). 'It is their nature to do menial labour': the racialization of 'Latino/a workers' by agricultural employers. Ethnic and Racial studies, 32(6), 1017-1036.

Miles, R., \& Brown, M. (2003). Racism. Psychology Press.

Moghadam, V. M. (2005). The'feminization of poverty'and women's human rights. UNESCO.

Morini, C. (2007). The feminization of labour in cognitive capitalism. Feminist review, 87(1), 40-59.

Murji, K., \& Solomos, J. (2005). Introduction: racialization in theory and practice. Oxford: Oxford University Press.

National Bank of Georgia (2016) Brief Migration Profile: Remittances. The European Union for Georgia.

Obolensky-Ossinsky, V. V. (1931). Emigration from and Immigration into Russia. In International Migrations, Interpretations. 521-580.

O'Loughlin, J., Kolossov, V. ve Radvanyi, J. (2007). The Caucasus in a time of conflict, demographic transition, and economic change. Eurasian Geography and Economics, 48(2), 135-156.

Oxfam (2020). Bakım Zamanı: Ücretlendirilmeyen ve Eksik Ücretlendirilen Bakım Emeği ve Küresel Eşitsizlik Krizi. Oxfam International.

Öksüz, M. (2018). "Buralarda yabanc1 yok”: Hemşehri derneklerinin kentlileşme üzerine etkisi, Ankara>daki Oflular örneği. Türk Coğrafya Dergisi, (70), 87-98.
Öksüz, M. (2019). Gürcistan>dan Türkiyesye Döngüsel Emek Hareketliliği: Süreçler, Paternler ve Sonuçlar. Ankara Üniversitesi, Yayınlanmamış Yüksek Lisans Tezi.

Özbay, F. (2017). Dünden Bugüne Aile, Kent, Nüfus. İstanbul: İletişim.

Özbey, K. (2018) Sinır Kapitalizmi Gürcistan'dan Türkiye’ye Günübirlik Işşi Göçü. Ankara: Siyasal Kitabevi.

Özkiraz, A., \& Acungil, Y. (2012). Hemşehri derneklerinin kentlileşme sürecindeki rolü (Tokat örneği). Hacettepe Üniversitesi Edebiyat Fakültesi Dergisi, 29(1), 247-272.

Pattnaik, I., Lahiri-Dutt, K., Lockie, S., \& Pritchard, B. (2018). The feminization of agriculture or the feminization of agrarian distress? Tracking the trajectory of women in agriculture in India. Journal of the Asia Pacific Economy, 23(1), 138-155.

Petrovici, N., Raţ, C., Simionca, A., \& Vincze, E. (2019). Introduction: Racialized Labour of the Dispossessed as an Endemic Feature of Capitalism. In Racialized Labour in Romania (pp. 1-38). Palgrave Macmillan, Cham.

Preibisch, K., \& Binford, L. (2007). Interrogating racialized global labour supply: an exploration of the racial/national replaceme of foreign agricultural workers in Canada. Canadian Review of Sociology/Revue canadienne de sociologie, 44(1), 5-36.

QUASTAT (2017). Food anda Agriculture Organization of United Nations. OUASTAT.

Reigada-Olaizola, A. (2011). Agrarian restructuring, labor migration and feminization of labor in Andalucía (Spain). Agricultura Sociedad y Desarrollo, 8(1), 19-43.

Richer, Z. (2012). Feminization of labor. The Wiley-Blackwell Encyclopedia of Globalization.

Sanmiguel-Valderrama, O. (2007). The feminization and racialization of labour in the Colombian fresh-cut flower industry. Journal of Developing Societies, 23(1-2), 71-88.

Sarı, M. (2014). Türkiye-Kafkasya İlişkilerinde Batum. Ankara: Afşaroğlu Matbaası.

Satzewich, V. (2000). Whiteness Limited: Racialization and the Social Construction of' Peripheral Europeans". Histoire sociale/Social History.

Sautman, B., \& Hairong, Y. (2016). The discourse of racialization of labour and Chinese enterprises in Africa. Ethnic and Racial Studies, 39(12), 2149-2168.

Steinbeck, J. (2018). Gazap Üzümleri. İstanbul: Sel Yayıncılık.

Szelenyi, I. (2001). Poverty, ethnicity, and gender in Eastern Europe during the market transition. Greenwood Publishing Group.

Teelucksingh, C. (2006). Claiming space: Racialization in Canadian cities. Waterloo: Wilfrid Laurier University Press.

Thomas, M. (2010). Neoliberalism, racialization, and the regulation of employment standards. Neoliberalism and everyday life, 68-89.

Toksöz, G., Dedeoğlu, S., \& Elveren, Y. (2012). Neoliberal Piyasa, Özel ve Kamusal Patriarka Çıkmazında Kadın Emeği. Türkiye'de Refah Devleti ve Kadin, 103-126.

Ulukan, N. C. ve Ulukan, U. (2018). Çay Tarımı ve Göçmen Emeği: Doğu Karadeniz'de Gürcü İşçiler. Labour economıcs \& ındustrıal relations, 101. 
Urhan, B., \& Etiler, N. (2011). Sağlık sektöründe kadın emeğinin toplumsal cinsiyet açısından analizi. Çalışma ve Toplum, 2(29), 191-215.

Vincze, E. (2019). Ghettoization: The production of marginal spaces of housing and the reproduction of racialized labour. In Racialized Labour in Romania (pp. 63-95). Palgrave Macmillan, Cham.

Vosko, L. F. (2002). The pasts (and futures) of feminist political economy in Canada: Reviving the debate. Studies in Political Economy, 68(1), 55-83.

Wacquant, L. J. (2015). Kent Paryalart: Ileri marjinalliğin karşılaştırmalı sosyolojisi. İstanbul: Boğaziçi Üniversitesi Yayınevi

World Bank (2018). World Bank In Georgia. World Bank Report.

Yıldırımalp, S., \& Özdemir, A. (2013). Yapabilirlikten yoksunluk bağlamında Türkiye'de kadın yoksulluğu. Hak $\dot{I}_{S ̧}$ Uluslararası Emek ve Toplum Dergisi, 2(4).

Yoshimura, M. (2007). Feminization of labor migration. The Blackwell Encyclopedia of Sociology.
Yücel, Y. G., \& Orhan, G. (2018). Yayıncılık Dünyasının Feminizasyonu Süreci: Kadın Çevirmenler Üzerine Bir İnceleme. Kebikec: İnsan Bilimleri İçin Kaynak Araştırmaları Dergisi, (46).

Yüceşahin, M. M. (2009). Türkiye'nin Demografik Geçiş Sürecine Coğrafi Bir Yaklaşım. Coğrafi Bilimler Dergisi, 7(1), 1-25.

Zaman, H. (2010). Racialization and marginalization of immigrants: A new wave of xenophobia in Canada. Alberta: Athabasca University Press.

Zelinka, A. (2017) Circular Short-Term Labor Migration from Armenia to Russia: The Issue of Time and Socio-Economic Effects on Family Life in Armenia. Austrian Studies in Social Anthropology.

Zihnioğlu, A. (2008 ). Bir Yeşilin Peşinde. TÜBİTAK Popüler Bilim Kitaplar1.

Zurabishvili, T., \& Zurabishvili, T. (2010). The feminization of labor migration from Georgia: the case of Tianeti. Laboratorium: Russian Review of Social Research, 2(1), 73-83. 
